\title{
Financialisation of the Food Value Chain, Common Ownership and Competition Law
}

\author{
Ioannis Lianos, Alina Velias, Dmitry Katalevsky and George Ovchinnikov*
}

\begin{abstract}
The paper delves into the implications of the financialisation process for competition law enforcement. We consider that the recent debate over common ownership and its impact on competition law and policy integrates one of the possible manifestations of the broader debate competition law should have on the financialisation of the economy. We focus on the food industry and explore the possibility that common ownership may constitute a competition concern, raising issues of unilateral effects, horizontal collusion, vertical exclusion and vertical exploitation. This discussion is particularly important in the context of Global Food Value Chains as many institutional investors are passive investors in the diverse companies that are active at various segments of the Global Food Value Chains. In view of the possible negative welfare effects of common ownership on competition and its prevalence in the food sector, it is contended that competition authorities need to develop adequate legal tools to deal with this issue and rely on economics but also other sources of wisdom (e.g. advanced social network analysis) that may enable a better mapping of the complexity of competitive interactions in this sector and be more adequate in the context of a complex economy. The paper sets the broader theoretical framework and proceeds to an empirical investigation of common ownership in the global food value chain using the tool of advanced social network analysis.
\end{abstract}

Keywords: financialisation, food value chain, common ownership, concentration, innovation, value chain, vertical competition, unilateral effects, coordinated effects, agrochem

JEL: G3, K21, L1, L4, Q14, Q18

\footnotetext{
* Ioannis Lianos is President of the Hellenic Competition Commission and professor of global competition law and policy at UCL Faculty of Laws; Alina Velias is Visiting Lecturer at Department of Economics, City University of London, Dmitry Katalevsky is Associate Professor at the Russian Presidential Academy of the National Economy and Public Administration and George Ovchinnikov is Research Scientist at the Skolkovo Institute of Science and Technology. The authors would like to thank Pierre Regibeau and Marco-Claudio Corradi for excellent comments. The authors are responsible for any errors or omissions. Views are personal and do not engage the Hellenic Competition Commission.
} 


\title{
Financialisation of the Food Value Chain, Common Ownership and Competition Law
}

\author{
Ioannis Lianos, Alina Velias, Dmitry Katalevsky and George Ovchinnikov*
}

I. INTRODUCTION

II. SETTING THE SCENE: THE FINANCIALISATION OF THE FOOD VALUE CHAIN..... 7

III. COMMON OWNERSHIP AS AN ILLUSTRATION OF FINANCIALISATION AND IMPLICATIONS FOR COMPETITION ASSESSMENT …...................................... 9

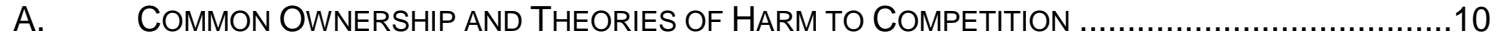

1. Unilateral or Non-Coordinated Effects ................................................................... 11

2. Common Ownership and Coordinated Effects................................................... 15

3. Common Ownership and Vertical Effects .............................................................. 17

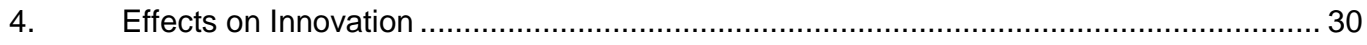

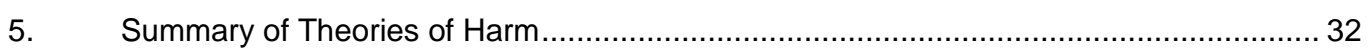

B. Beyond Traditional Competition (Price and InNovation) Effects: Effects on Long-Term SUSTAINABILITY.....

1. Evaluation of the Effects of Financialisation on the Food Value Chain: Evidence and Controversy 35

2. The Prevalence of Common Ownership in the Global Food Value Chain: Empirical Evidence and Possible Effects

IV. IS COMPETITION LAW READY FOR FINANCIALISATION?.... 44

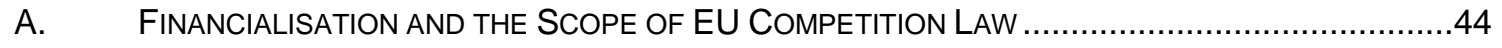

B. COMPETITION LAW FRAMEWORK FOR COMMON OWNERSHIP. .53

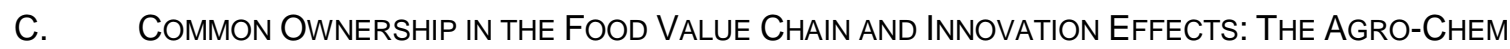
MERGERS

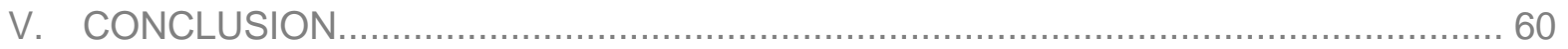

\section{Introduction}

\footnotetext{
* Ioannis Lianos is President of the Hellenic Competition Commission and professor of global competition law and policy at UCL Faculty of Laws; Alina Velias is Visiting Lecturer at Department of Economics, City University of London, Dmitry Katalevsky is Associate Professor at the Russian Presidential Academy of the National Economy and Public Administration and George Ovchinnikov is Research Scientist at the Skolkovo Institute of Science and Technology. The authors would like to thank Pierre Regibeau and Marco-Claudio Corradi for excellent comments. The authors are responsible for any errors or omissions. Views are personal and do not engage the Hellenic Competition Commission.
} 
The 'financialisation' of the global economy has been described as "a recurrent trend affecting a number of markets". ${ }^{1}$ Since the development of the multi-product firm in the 1970s, corporate control has undergone a fundamental transformation. Managers of this type of firm sought to spread risks across various product lines in order to achieve greater profitability whilst simultaneously growing the firm through mergers financed by leveraged buyouts, private equity and other innovative financial techniques. As a result of this, the level of corporate (but also household) debt has considerably increased.

The process of financialisation in relation to the modern corporation has been a key feature of this transformation. It resulted in a substantial increase in the total corporate profits of the financial sector (a sector comprised of the areas of finance, insurance and real estate) from $10 \%$ in 1950 to roughly $45 \%$ in 2001, whilst in this same period the profits of the manufacturing sector dropped substantially. ${ }^{2}$ It also led to a significant increase in the share of financial assets held by economic actors not operating in the financial sector of the economy and in the importance of financial revenue for non-financial businesses. ${ }^{3}$ This period coincides with the prevalence of the 'shareholder value' or 'shareholder primacy' principle, ${ }^{4}$ which, since the 1970 s, has dominated, mostly in the US, corporate governance discourse and its subsequent focus on short-term share price. ${ }^{5}$ This principle has changed managerial priorities from those of maximising growth by re-investing corporate savings in the long-term, productive potential of the corporation (i.e. the 'retain and re-invest' principle) to maximising stock value through extensive buybacks of corporate stocks (i.e. 'share repurchase') in order to inflate stock prices as the resulting artificial scarcity of shares boosts their value. ${ }^{6}$

Disciplined by a corporate market for control that is dominated by financial interests, particularly those of institutional investors, corporate managers have progressively aligned their own interests with those of shareholders and have adopted strategies aimed at increasing the price of their corporate stocks. They have downsized their corporations, by cutting labour costs in particular, in order to create short-term shareholder value and distribute the consequently freed-up corporate revenues to those with financial interests, particularly

\footnotetext{
${ }^{1}$ More generally, see G. Epstein, Financialization and the World Economy, (Edward Elgar, 2005); R. Shiller, The New Financial Order. Risk in the 21st Century, (Princeton University Press, 2003); J. Montgomerie and K. Williams, Financialised Capitalism: After the Crisis and Beyond Neoliberalism, 13 Compet. and Chang. 99-107 (2009); E. Engelen, The Case for Financialization, 12 Compet. and Chang. 111-119 (2008); N. van der Zwan, Making Sense of Financialization, 12(1) Socio-Economic Rev. 99-129 (2014); R. Solow, How to Save American Finance from Itself - Has Financialisation Gone Too Far?, newrepublic.com, 8 April 2013, <http://www.newrepublic.com/article/112679/how-save-american-finance-itself>.

${ }^{2}$ G. Epstein, Financialization and the World Economy, 1-2 (Edward Elgar, 2005).

${ }^{3}$ Id. 15.

4 W. Lazonick and M. O' Sullivan, Maximizing Shareholder Value: A New Ideology for Corporate Governance, 29(1) Economy and Society 13 (2000).

${ }^{5}$ L. Davis, The Financialization of the Non-Financial Corporation in the Post-1970s U.S. Economy, Dr. Diss. 175 (2014). In most European countries 50 to $60 \%$ of the economy was under state control, at least until the privatizations that occurred in the 1980s and 1990s. As to EU member states' private companies, the shareholder value maximization principle has been (re) introduced in the 1990s in most countries, hence financialsiation is a more recent phenomenon in the EU.

${ }^{6}$ See W. Lazonick, Profits Without Prosperity, Harv. Bus. Rev. (2014), https://hbr.org/2014/09/profits-withoutprosperity ; L. Palladino, Stock Buybacks: Driving a High-Profit, Low-Wage Economy, Report of the Roosevelt Institute (2018), <https://rooseveltinstitute.org/stock-buybacks-high-profit-low-wage/>.
} 
shareholders, instead of re-investing them in the corporation (i.e. the 'downsize and distribute' principle). ${ }^{7}$

An important facet of the financialisation movement has been the increasing leveraging of corporations through debt and other hybrid financial instruments. This, in turn, has led to corporations becoming more dependent on the investments of some institutional investors, which increasingly own shares in publicly listed companies, instead of physical persons. ${ }^{8}$ Lazonick and O'Sullivan have highlighted how "the rise of the institutional investor as a holder of corporate stocks encouraged top managers to align their own interests with external financial interests [rather] than with the interests of the productive organisations over which they exercised control". ${ }^{9}$ This literature has also shown how financial profits (mainly interest and dividend income as well as realised capital gains) form a significant part of corporate cash flow, with growing financialisation being inversely related to fixed investment. ${ }^{10}$ The abandonment of the 'retain and re-invest' principle in favour of buybacks has, indeed, been considered to be one of the main reasons for the stagnation in productivity that has been witnessed since the 1980s - the economy has been "starved" of productive investments. ${ }^{11}$ The increase in non-financial corporations holding financial assets has led to a shift in the composition of firms' portfolios from fixed capital towards liquid financial assets, such as cash and short-term investments. There has also been a rise in leveraging, in particular for larger firms, which have become more and more focused on stock market performance, while non-publicly traded smaller and medium firms have slowly deleveraged their balance sheets. ${ }^{12}$

The rise of institutional investors constitutes an epiphenomenon within the context of the financialisation of the economy. They are a disparate group of legal entities the purpose of which is mostly to manage and invest other people's money, although this is not always the case and as there are hybrid forms of equity funds in which limited partners provide the 'real' financial investment, while managing and general partners provide the human

\footnotetext{
${ }^{7}$ Lazonick, supra, at 6.

${ }^{8}$ S. Çelik and M. Isaksson, Institutional investors and ownership engagement, 2 OECD J. Financ. Mark. Trends 94 (2013), which notes that only $10 \%$ "of all public equity is today held by physical persons.

${ }^{9}$ Lazonick and O' Sullivan, supra, at 4, 27.

${ }^{10}$ E. Stockhammer, Financialisation and the Slowdown of Accumulation, 28(5) Cambridge J. Econ. 719 (2004) ; Davis, supra at 5, 17.

${ }^{11}$ I. Tung and K. Milani, Curbing Stock Buybacks: A Crucial Step to Raising Worker Pay and Reducing Inequality. An Analysis of Three Industries - Restaurant, Retail, and Food Manufacturing, Report of the National Employment Law Project and Roosevelt Institute (2018), <http://rooseveltinstitute.org/wpcontent/uploads/2018/07/The-Big-Tradeoff-Report_072618.pdf> which shows how buybacks in three segments of the food industry value chain reduce the availability of corporate resources for growth-inducing activities, such as investing in research and development, spending on capital investments and new technologies, creating new jobs and/or improving worker compensation. Similar research should also be completed with regard to firms in Continental Europe, the trend in the UK being largely similar to that in the US. However, recent evidence indicates that this buyback frenzy is also catching up with continental EU-based firms: see https://www.bloomberg.com/news/articles/2018-08-13/europe-finally-gets-its-share-of-mega-buybacks-asprofits-grow ; M. E. Sakinç, Share Repurchases in Europe A Value Extraction Analysis, ISI Growth, May (2017), 〈http://www.isigrowth.eu/wp-content/uploads/2017/06/working_paper_2017_16.pdf >. For some less recent work, see H. von Heije, W.L. Megginson, Dividend and Share Repurchases in the European Union, 89(2) J. Financ. Econ. 347 (2008) .

${ }^{12}$ Davis, supra, at 5, 44.
} 
skills/expertise. ${ }^{13}$ These institutional investors include traditional financial investors, such as investment funds (in particular index funds), pension funds and insurance companies, as well as 'alternative' institutional investors, such as hedge funds, private equity funds, sovereign wealth funds and exchange traded funds, and asset-management firms ${ }^{14}$ The degree of engagement of these institutional investors in the competitive strategy of the corporations in which they invest varies. One may contrast active hedge funds with index funds, which are investment funds (mutual funds or exchange traded funds) that mechanically track the performance of an index and are presumed to be "passive" as they have little incentive to invest in the stewardship of the companies in which they invest. Hence, they defer excessively to the viewpoints of corporate managers. ${ }^{15}$ Due to their passive nature, they are not concerned with firm-level performance, in contrast with active shareholders; rather to the extent they are investing in a group of companies, they are concerned with the performance of their portfolio of firms. However, they do not engage in the governance of their portfolio companies (although one should not exclude that they may also take some forms of activism too).

In recent years, both institutional investors and the asset management market have witnessed substantial concentration. Recent research has found that the twenty largest asset management firms around the globe account for $43.3 \%$ of the top 500 managers' total assets under management ('AUM') and, in 2017, this amounted to \$93.8 trillion (USD). These figures illustrate the highest level of concentration since, at least, $2000 .{ }^{16}$ Passive index funds, such as BlackRock with \$6.3 trillion total AUM , Vanguard Group with \$4.9 trillion total AUM and State Street Global with $\$ 2.7$ trillion, constitute the top three global asset managers in 2017, and are known as 'The Big Three'. ${ }^{17}$ Following them is Fidelity, an active mutual funds management fund with $\$ 2.4$ trillion AUM. ${ }^{18}$ The concentration of corporate ownership resulting from the concentration of the asset management market may lead to index funds seeking to be more engaged in corporate strategy and in influencing corporate management. Index funds may choose to exercise their voting power but, equally, they may choose to do nothing. Whichever course of action or inaction is pursued, this may induce the relevant corporate management to internalise the index funds' interests in competing firms, in view of the fact that their importance in the shareholding has become more important in recent years. ${ }^{19}$ The rise of common ownership and the concentration of the asset management

\footnotetext{
${ }^{13}$ Çelik and Isaksson, supra, at 8, 96.

${ }^{14} \underline{\mathrm{Id}}$.

${ }^{15}$ For a discussion, L. Bebchuk and S. Hirst, Index Funds and the Future of Corporate Governance: Theory, Evidence, and Policy, (European Corporate Governance Institute ('ECGI') - Law Working Paper No. 433/2018, 2018).

16 Thinking Ahead Institute, The World's Largest 500 Asset Managers - Year Ended 2017, (October 28, 2018), $<$ https://www.thinkingaheadinstitute.org/en/Library/Public/Research-and Ideas/2018/10/PI5002018_research_paper>.

${ }^{17}$ J. Fichtner, E. Heemskerk and J. Garcia-Bernardo, Hidden Power of the Big Three? Passive Index Funds, ReConcentration of Corporate Ownership and New Financial Risk, 19(2) Bus. and Pol. 298 (2017).

${ }^{18}$ Thinking Ahead Institute, supra, at 16, 38.

${ }^{19}$ See M. Schmalz, Common-Ownership Concentration and Corporate Conduct, 10 Annu. Rev. Financ. Econ. 444 (2018); S. Hemphil and M. Kahan, The Strategies of Anticompetitive Common Ownership, www.ssrn.com, (NYU Law and Economics Research Paper No. 18-29 2018), which distinguishes between macro-mechanisms
} 
market may have contributed considerably to the loss of dynamism in the economy, the drop in productivity and the rise of firm mark-ups. ${ }^{20}$

The combined effects of shareholder primacy, the rise of common ownership and the concentration of asset management have important implications on the competitive strategies undertaken by the management of a corporation. They challenge the notion of 'own-firm profit' or 'value maximisation', a notion that had animated industrial capitalism since the $1930 \mathrm{~s},{ }^{21}$ and formed a key part of the neoclassical theory of the 'corporation'. ${ }^{22}$ Subsequent literature challenged the 'separation' theorem. It has found that, in the late 1970s, the shift towards shareholder primacy, the emergence of financialisation and the reduction in the dispersion of shareholdings of public corporations due to the rise in common ownership, may have multiple effects. One effect may be to increase the influence of shareholders in determining the 'utility' function of the corporations in which they invest, thereby, challenging one of the assumptions of the 'Fisher separation' principle. Another may be that shareholders, rather than opt for own- firm profit or value maximisation, seek to maximise the value of their whole shareholding portfolio in all firms present in the industry in which they have invested. This, in turn, may result in the alteration of corporate managers' incentives to aggressively compete on product markets with competing firms in which the common owners also hold shares. ${ }^{23}$

The important development of the capitalist economy engendered by financialisation is particularly visible in the structure of the food value chain ('FVC') during the last few decades. As we explain in Part II, in addition to the development of future markets in agricultural commodities, the process of financialisation has profoundly affected the organisation of the FVC, in particular with the increasing presence of institutional investors. The recent agro-chem mega-mergers gave the European Commission and other competition authorities worldwide the opportunity to, for the first time, engage in an in-depth consideration of the competition implications of the financialisation process. Their focus has been one of the most visible aspects of financialisation, the rise of common ownership by institutional investors in the food sector, an issue thoroughly examined in Part III. As we

and micro-mechanisms, which may account for the influence common-owners may exercise over a firm's management, and critically reviews the effectiveness of the different mechanisms.

${ }^{20}$ See J. Shambaugh, R. Nunn, A. Breitwieser and P. Liu, The State of Competition And Dynamism: Facts about Concentration, Start-Ups and Related Policies, Technical Report of the Hamilton Project (2018); G. Gutiérrez and T. Philippon, Investment-Less Growth: An Empirical Investigation, Technical Report of the National Bureau of Economic Research (2016); J. De Loecker and J. Eeckhout, The Rise of Market Power and the Macroeconomic Implications, (National Bureau of Economic Research, Working Paper 23687, 2017 ); M. Backus, C. Conlon, M. Sinkinson, The Common Ownership Hypothesis: Theory and Evidence, Report of Brookings Economic Studies (2019), which found less of a link between concentration in asset management and common ownership incentives than between a broader increase in diversification of investor portfolios and common ownership incentives.

${ }^{21}$ This stems from the 'Fisher separation theorem', which stipulates that the goal of any firm is to increase its profits and present value to the fullest extent, the profit goals of the firm being completely separate from its diverse shareholders: see I. Fisher, The Theory of Interest (Macmillan, 1930). This principle stops the firm from caring about the shareholders' utility function, which is also a ramification of the separation of management and control as envisaged by A. Berle and G. Means, The Modern Corporation \& Private Property (Routledge, $2^{\text {nd }}$ ed, 1991, first published in 1932).

${ }^{22}$ For an interesting discussion, see H. Hovenkamp, Neoclassicism and the Separation of Ownership and Control, Faculty Scholarship at Penn Law 1792 (2009).

${ }^{23}$ For a detailed discussion, see Schmalz, supra, at 19, 413. 
show in the subsequent Parts, financial investors are present in all but one stage of the FVC, specifically that of farming. This has profound implications on the degree of concentration in he industry, which may, in turn, have an effect on prices, output, innovation and other social costs. This chapter engages with the rise of common ownership in the global FVC and the various theories of harm of common ownership. The final Part examines the tools and concepts developed by competition authorities, in particular the European Commission, to deal with the social costs of common ownership and, more broadly, financialisation.

\section{Setting the Scene: The Financialisation of the Food Value Chain}

Trade in agricultural commodities serves as a useful illustration of the ongoing process of financialisation in the FVC. An important step in this process was the creation of a tradable commodity price index. The first such index was established in the Unites States in the early 1940s, and was known as the Bureau of Labour Statistics Spot Commodity Index. In 1991, this was replaced by the Goldman Sachs Commodity Index ('SP-GSCI'). This enabled investors to bet on commodities by simply buying a swap contract from Goldman Sachs, "without having to participate in formal futures markets with their position limit restrictions". ${ }^{24}$ The next step in this process of financial innovation was the creation of Exchange Traded Funds ('ETFs'). These enabled institutional and retail investors to add commodities to their portfolios, thereby transforming commodities to a new asset class. ${ }^{25}$ The financialisation of commodity markets culminated with the passage of the Commodity Futures Modernization Act ('CFMA') of 2000, which, in turn, led to a phenomenal increase of the swaps market. In order to avoid price manipulation, the CFMA required that all agricultural futures be traded on a Commodity Futures Trading Commission (CFTC)regulated exchange. However, it also allowed for the possibility of an exemption if such "would be consistent with the public interest". ${ }^{26}$ Premised on the understanding that financial investments would not influence spot prices, this provision was widely interpreted and led to a "tremendous flow of funds" into commodities. ${ }^{27}$ Essentially, the CFMA led to a deregulation of futures trading for agricultural commodities, financial interests dominating now futures trading and accounting for $70 \%-80 \%$ of open interest in many markets. ${ }^{28}$

Following the 2008 commodity price bubble, the CFTC proposed the establishment of speculative position limits for a number of previously exempted agricultural commodity futures and option contracts. In October 2011, it adopted these new position limit rules. However, these rules were successfully challenged in the courts. The courts interpreted the Dodd-Frank Wall Street Reform and Consumer Protection Act of 2010 ('Dodd-Frank Act'), the statutory legal basis for action being taken by the CFTC, as requiring the CFTC, when establishing new position limits, to prove that speculative limits were necessary in order to avoid excessive speculative positions that could lead to higher prices in interstate commerce. Consequently, the CFTC had to propose new limits and it did so in 2013.

\footnotetext{
${ }^{24}$ T. Schmidt, The Political Economy of Food and Finance, 60 (Routledge, 2016).

${ }^{25}$ Id. 63.

${ }^{26}$ Id. 65.

${ }^{27} \mathrm{Id}$.

${ }^{28} \underline{\underline{\mathrm{Id}}}$
} 
Financial speculation concerning agricultural commodities has been facilitated by the creation of new financial devices. The aim of such devices has been to establish private insurance markets through forward trading, which could replace the existing, public, pricecontrol mechanisms that seek to protect farmers from market-price fluctuations. For instance, the Food Corporation of India, a public body established in 1964, seeks to act as a cross between a marketing board, a food bank and a subsidy scheme. When it intervenes, it does so with the aim of protecting farmers from the volatility of market prices, thereby acting as a public insurance mechanism. ${ }^{29}$ Yet the development of such commodity futures trade triggers, through self-reinforcing speculation, price fluctuations and, thus, puts farmers at the mercy of big market actors, such as one-stop-shop corporations which provide farmers with insurance with regard to their yields.

As Ghosh states in relation to commodity futures trading, "the declared purpose of forward trading and of futures markets is to allow for hedging against price fluctuations, whereby the selling of futures contracts would exceed the demand for them. This implies that futures prices would be lower than spot prices, or what is known as 'backwardation'. However, throughout much of the period from January 2007 to June 2008, the markets were actually in contango, in which futures prices were higher than spot prices. This cannot reflect the hedging function and must imply the involvement of speculators who are expecting to profit from rising prices". 30

The development of the commodity futures market challenged another tenet of neoclassical price theory. It separated the formation of prices from the standard supply and demand interaction. The latter reflects the preferences of the consumers based on the choices they make in the marketplace (i.e. their 'revealed preferences'). However, the development of the commodity futures market has resulted in the price, rather than being linked to consumers' revealed preferences, being linked to the views of financial investors about the future evolution of demand, which may, in fact, prove to be irrational. It is hard to imagine how a competition law that ignores the formation of commodity prices could operate if it fails to integrate into the analysis the contango-inducing dynamics of commodities future trading and the externalities that such pseudo-market configurations may produce on the different economic actors involved, such as farmers, final consumers, processors etc. This dimension of financialisation is an important part of competition as one of the main purposes of competition law is to protect the process of signalling preferences and the diffusion of information resulting from the price system.

A second illustration of the increasingly important role of financialisation is the growing role of institutional investors and private equity in the food industry. Schmidt reports that of the 281 deals reported in the food and beverage industry in 2013, investment firms and banks were involved in 47 of these deals (i.e. in 15\%). ${ }^{31}$ A number of the largest companies operating in and across various segments of the value chain are privately held corporations, most notably grain companies, while a number of companies at the retail level have a mixed

\footnotetext{
${ }^{29}$ L. Russi and T. Ferrando, Capitalism a Nuh' Wi Frien'. The Formatting of Farming into an Asset, From Financial Speculation to International Aid, 6(1) Catalyst - A Social Justice Forum 3 (2015).

${ }^{30}$ J. Ghosh, The Unnatural Coupling: Food and Global Finance, 10(1) J. Agrar. Change, 78-79 (2010).

${ }^{31}$ T.P. Schmidt, supra, at 24, 111.
} 
ownership structure. ${ }^{32}$ Moreover, a number of institutional investors, including but not limited to sovereign wealth funds and privately held corporations, are investing in agricultural land, in particular global farmland. For the time being, this is limited, as the farming segment of the FVCs constitutes, in relative terms, the market that looks, at least on a global scale, closer to atomistic competition. This has led to a backlash from some quarters, which have raised the problem of global farmland grab as a major public policy concern. ${ }^{33}$

Broadening the capabilities of competition authorities to envision tools and frameworks that respond to the increasing financialisation of the FVC constitutes a serious challenge, particularly in light of the rapidly increasing economic concentration of some of the segments of the FVC and the phenomenon of 'stealth concentration' or 'common ownership'. The latter involves the same institutional investors of different companies investing and holding shares in multiple segments of the FVC. The increasing financialisation of the FVC was analysed by certain competition authorities in recent, food-sector merger cases.

\section{Common Ownership as an Illustration of Financialisation and Implications for Competition Assessment}

As previously highlighted, the financialisation of the economy has led to institutional investors occupying a more important role in the global economy. ${ }^{34}$ However, it is only relatively recently that an overlap in shareholders, as observed in situations of 'common ownership', i.e. situations in which several companies are owned or influenced by one person or organisation, and 'cross-ownership', i.e. situations in which two companies hold shares in each other), has attracted the attention of competition authorities. The possible anticompetitive incentives created by common ownership, but also by cross ownership, in concentrated product and geographic markets have been long recognised in theoretical literature, ${ }^{35}$ however, such contentions often but lacked sufficient empirical evidence. ${ }^{36}$

\footnotetext{
${ }^{32}$ Id. 114.

${ }_{33}$ P. McMichael, The Land Grab and Corporate Food Regime Restructuring, 39(3) and 39(4) J Peasant Stud. 681 (2012).

${ }^{34}$ Posner, Morton and Weyl note that "institutional investors owned 70-80\% of the US stock market, up from $7 \%$ in 1950 . When combined, BlackRock, Vanguard, and State Street constitute the single largest shareholder of at least $40 \%$ of all public companies in the US. They constitute the largest owner in nearly $90 \%$ of public companies in the S\&P 500, up from 25\% in 2000. The fraction of US public firms held by institutional investors who simultaneously hold large blocks of other same-industry firms increased from less than $10 \%$ in 1980 to about 60\% in 2010", see E. Posner, F. Morton and E. Weyl, A Proposal to Limit the Anti-Competitive Power of Institutional Investors, (University of Chicago Coase-Sandor Institute for Law and Economics, Research Paper No. 787, 2016) Although the role of institutional investors is more limited in Europe, similar concerns may be raised.

${ }^{35}$ See J. Rotemberg, Financial Transaction Costs and Industrial Performance, (Massachusetts Institute of Technology, Alfred P. Sloan School of Management., Working Paper No. 1554-84, 1984); T Bresnahan and S. Salop, Quantifying The Competitive Effects of Production Joint Ventures, 4 Int. J. Ind. Organ., 155 (1986); R. Reynolds and B. Snapp, The Competitive Effects of Partial Equity Interests and Joint Ventures, 4 Int. J. Ind. Organ. 141 (1986); R. Gordon, Do Publicly Traded Corporations Act in the Public Interest?, (National Bureau of Economic Research, Working Paper No. 3303, 1990); D. O'Brien and S. Salop, Competitive Effects of Partial Ownership: Financial Interest and Corporate Control, 67 Antitrust Law J. 559 (2000); Posner et al., supra, at 34; D. Gilo, The Anticompetitive Effects of Passive Investment, 99 Mich. Law Rev. 1 (2000); D. Gilo, Y. Moshe and Y. Spiegel, Partial Cross Ownership and Tacit Collusion, 37(1) RAND J. Econ. 81 (2006).
} 
Recent empirical analyses on common ownership in the American airline industry ${ }^{37}$ and banking industry ${ }^{38}$ have reignited the debate. They measured the potential effect of common ownership on price levels and whether they may lead to prices rising above a level which would be competitive. These findings resulted in policy concerns, ${ }^{39}{ }^{40}$ and proposals for legislative intervention, ${ }^{41}$ but also there was criticism of the aforementioned findings. ${ }^{42} 43$

We examine the emerging economic framework for common ownership and current debates concerning the anti-competitive potential of common ownership. We explore the possibility of unilateral effects before proceeding to analyse possible coordinated effects, vertical foreclosure and vertical exploitative behaviour, which constitute additional theories of harm for common ownership. We then explore the legal framework that would be relevant to tackle the alleged anti-competitive effects of common ownership and financialisation before delving into the prevalence of common ownership and financialisation in the food sector, in an attempt to draw some implications for competition law and policy.

\section{A. Common Ownership and Theories of Harm to Competition}

We consider four major mechanisms through which common ownership may be causing adverse effects to competition and harming consumers and the economy, specifically: (i) unilateral effects or non-coordinated effects, (ii) coordinated effects (i.e. 'tacit collusion'), (iii) vertical foreclosure through raising rivals' costs strategies, and (iv) vertical exploitative behaviour (i.e. gaining higher profit margins at the expense of reduced margins for the competitive segment of the value chain). ${ }^{44}$

The possible unilateral or non-coordinated effects of common ownership on the economy is a hotly debated topic and we sketch the main themes of this debate. In this chapter, we neither conduct an in-depth analysis of the way in which common ownership may be feeding into a possible concern of coordinated effects, thereby exacerbating the possibility for tacit coordination in the market, nor of the availability of different measurement tools to assess its effects. ${ }^{45}$ Rather, we consider the established mechanisms of foreclosure available to vertically-integrated investors. We discuss them in light of recent

\footnotetext{
${ }^{36}$ See, the concerns expressed by O'Brien and Salop, supra, at 35, 559.

${ }^{37}$ J. Azar, M. Schmalz and I. Tecu, Anticompetitive Effects of Common Ownership, 73(4) J. Financ. 1513 (2018).

${ }^{38}$ J. Azar, R. Raina and M. Schmalz, Ultimate Ownership and Bank Competition, www.ssrn.com (2016), https://papers.ssrn.com/sol3/papers.cfm?abstract_id=2710252.

39 Council of Economic Advisors, Benefits of Competition and Indicators of Market Power, (2016), https://obamawhitehouse.archives.gov/sites/default/files/page/files/20160414_cea_competition_issue_brief.pdf.

${ }^{40}$ E. Elhauge, Horizontal Shareholding, 129 Harvard Law Rev. 1267(2016).

${ }^{41}$ Posner et al., supra, at 34.

${ }^{42}$ E. Rock and D. Rubinfeld, Defusing the Antitrust Threat to Institutional Investor Involvement in Corporate Governance, (NYU Law and Economics, Research Paper No. 17-05, 2017).

${ }^{43}$ E. Rock and D. Rubinfeld, Antitrust for Institutional Investors, (NYU Law and Economics, Research Paper No. 17-23 2017).

${ }^{44}$ For the first two, see also, with regard to cross-ownership, the discussion in A. Tzanaki, The Regulation of Minority Shareholdings and Other Structural Links Between Competing Undertakings: A Law and Economics Analysis, UCL Doctoral Thesis (PhD) (2017).

${ }^{45}$ I. Lianos, A. Velias and A. Medina, Common Ownership and Competition - Theories of Harm and Measurement in Horizontal and Vertically Integrated Markets (forthcoming 2019).
} 
evidence of the increased financialisation of the food markets and negative effects on the farmer segment. We then explore additional possibilities through the development of exploitative theories of harm. We specifically highlight the lack of insight into the role of common ownership in a vertical context and explore possible directions for further research.

\section{Unilateral or Non-Coordinated Effects}

Economic literature has already highlighted the anti-competitive potential of crossownership. O'Brien and Salop note that even if firms do not collude, either expressly or tacitly, the incentives driving cross ownership are likely to result in an anti-competitive outcome. ${ }^{46}$ Building on this model, they outline a framework in which each firm sets its price independently and 'unilaterally', i.e. it neither bases its prices on those of its competitors nor does it assume that its pricing decision will have any effect on the prices charged by its competitors. Yet, both the aforementioned authors contend that the outcome may still be anticompetitive. ${ }^{47}$ The key element of the framework is that the objective function of the firm's management considers the extent to which a firm's most powerful owners are also the owners of its natural competitors. Therefore, the anti-competitive outcome of this framework is driven by two mechanisms that are generated by cross ownership: the financial mechanism and the control mechanisms.

The financial mechanism is purely structural. Cross ownership links the fortunes of actual and/or potential competitors thereby producing a positive correlation between their profits $^{48}$. The manager of one firm may have a financial interest in the profits of other firms his incentives being affected by the cross ownership. For instance, if Firm A owns some stock in Firm B and the manager of Firm A is judged on the total profit of Firm A, then, indeed, the manager of Firm A will behave less aggressively with Firm B. However, if the stock in Firm A is only owned by some of the owners in A, then the manager of Firm A will only care if these specific owners exert significant control or influence on Firm A. The linking of profits incentivises the firms to compete less vigorously than they otherwise would against one another and to adopt behaviour more conducive to joint profit maximisation. ${ }^{49}$

A second reason that cross ownership might diminish competition arises if the acquisition of shares by Firm A gives it some degree of corporate influence over the management of another firm or firms. This concerns situations in which a firm, Firm A, would exercise its corporate governance powers in other firms in the market in order to restrain these other firms from pursuing competitive courses of action that may harm its (Firm A's) profits. ${ }^{50}$

The financial incentive is more striking from the economic theory perspective. The theory suggests that cross ownership has the capacity to shift the incentives of the firms away

\footnotetext{
${ }^{46}$ See O'Brien and Salop, supra, at 35, 559; T. Bresnahan and S. Salop, Quantifying The Competitive Effects of Production Joint Ventures, 4 Int. J. Ind. Organ. 155 (1986).

${ }^{47}$ O'Brien and Salop, supra, at 35, 559.

${ }^{48}$ See, however, D. Malueg, Collusive behavior and partial ownership of rivals, 10(1) Int. J. Ind. Organ. 27 (1992) (finding that increasing cross ownership may reduce the likelihood of collusion).

${ }^{49}$ See further, Reynolds and Snapp, supra, at 35, 141.

${ }^{50}$ For detailed discussion, see D. O'Brien and K Waehrer, The Competitive Effects of Common Ownership: We Know Less than We Think (2017), https://papers.ssrn.com/sol3/papers.cfm?abstract_id=2922677
} 
from competition and towards maximising the owners' financial returns (both from the firm itself and from other firms in the same market). Such maximisation would not require any action to be taken by the cross-owners. ${ }^{51}$

Hence, according to the literature, the objective function of the management of a firm includes considering owners' earnings. ${ }^{52}$ The weight of the profit made by each owner on the objective function can be interpreted as a measure of the degree of control or influence that the relevant owner has over the managers of the firm. For example, in a case where the owner has no control over the manager, the weight of this owner in the manager's objective function consists only of this owner's financial interest. Consequently, this weight is lower than the weight of an owner who has the same ownership percentage, i.e. the same financial interest, but also has significant influence over the governance, i.e. voting shares, but also through looser forms of influence of the governance of the firm, such as situations of economic and financial dependence of the majority of the members of the board of directors.

Until recently, there has not been a theoretical framework for evaluating the effects on the market of 'common ownership', i.e. the simultaneous ownership by an investor of small stockholdings in several competing companies. Recent theoretical work attempted to fill this gap by developing a model of a firm behaviour in an oligopolistic setting in which the firm aggregates shareholder objectives, including that of common ownership. ${ }^{53}$ The framework posits the following premise: a common shareholder with equal shares in all firms in the market cannot benefit from competition and, therefore, will not encourage it. If one firm competes aggressively for market share, this share comes at the expense of the other firms in the market. The decrease in revenues for other firms, however, is greater than the increase in revenues for the aggressively competitive firm. For example, in the simplest version of an oligopolistic market, two firms, A and B, are of equal size. If Firm A undercuts Firm B's price in order to attract customers from Firm B, Firm A gains market share and sells many more products at this slightly reduced price. The average price on the market is lower while the total number of customers remains the same. Hence, the effect on the total producer rents on the market is negative. Consequently, an investor holding equal-sized stakes in Firms A and B enjoys greater total (i.e. portfolio) profits when the firms set prices or quantities as if they were two divisions of a monopoly. Hence, only separate owners have interest in an aggressive competitive strategy. However, if separate owners are not the most influential shareholders then the firm is not likely to support such a strategy.

Note that the economic incentive remains, independent of any coordination or communication among the firms. On a base level, anti-competitive effects arise from the interlocking of shareholdings, which diminish the incentives of each individual firm to cut prices or to expand output, which could reduce the number of sales made by rivals, thereby increasing their costs. Managers actively demanding reduced competition in order to drive up

\footnotetext{
${ }^{51}$ Although one may also raise the question as to why a manager would maximise such a weighted sum rather than care only about those in control.

${ }_{52}$ O'Brien and Salop, supra, at 35, 559.

53 J. Azar, A New Look at Oligopoly: Implicit Collusion Through Portfolio Diversification (2011), <https://papers.ssrn.com/sol3/papers.cfm?abstract_id=1993364>.
} 
profit margins in the portfolio may be driven by the desire for a "quiet life". 54

Empirical research has indeed demonstrated links between common ownership and industry-level profit margins, ${ }^{55}$ and between firm-level profitability and market shares. ${ }^{56}$ There are various studies which have found common ownership as having an effect on product prices.

Authors have applied the concept of common ownership to the American airline industry. ${ }^{57}$ They found common ownership concentration at levels that they considered likely to yield regulatory concerns. They also found that common ownership had an impact on airfares, estimated to be in the range of 3\%-12\%. However, it should be noted that their research demonstrates that the ownership structure of most of the large US airlines, barring Virgin, does not involve owners with significant influence - the largest shares of stock a single investor was found to hold was under $20 \%$. The authors used this fact to support their claim that there are no owners with significant influence who are interested in competition between these airlines.

Similarly, common ownership in the American banking industry was explored. ${ }^{58}$ Authors found a causal link between high levels of concentrated common ownership and higher prices for banking products. Among the top five beneficial owners of the six largest banks, three companies were always present (Blackrock, Vanguard and State Street), whilst Berkshire Hathaway and/or Fidelity were present in most cases. ${ }^{59}$ The authors found that higher levels of cross ownership and common ownership, as measured by the HerfindahlHirschman Index ('HHI'), had a positive and highly significant effect on fees and thresholds for interest-bearing checking accounts, estimating an \$0.80-\$1.16 (USD) higher average fee growth and a \$900-\$1,200 higher threshold growth for the top tercile countries in their dataset. Whilst the acceptable levels of market concentration can be debated, the rise of industry prices above the competitive level poses as the main concern for policy-makers.

Subsequent empirical studies found common ownership as having an effect on prices in the seed sector ${ }^{60}$ and in the food sector (ready-to-eat cereal) ${ }^{61}$ and on barriers to market entry in the pharmaceutical sector. ${ }^{62}$ On a global scale, certain authors have computed the implied profit weights that firms in the Standards and Poor's 500 Index ('S\&P 500') have for other firms in the Index over time. ${ }^{6364}$ They show that by the end of 2017 , an average S\&P

\footnotetext{
${ }^{54}$ See J. Hicks, Annual Survey of Economic Theory: The Theory of Monopoly, Econometrica: J. Econ. Soc. 1-20 (1935). For recent empirical evidence, see M. Bertrand and S. Mullainathan, Enjoying the Quiet Life? Corporate Governance and Managerial Preferences, 111(5) J. Polit. Econ. 1043-1075 (2003).

55 Azar, supra, at 53.

${ }^{56} \mathrm{~J}$. He and J. Huang, Product Market Competition in a World of Cross-Ownership: Evidence from Institutional Blockholdings, 30(8) Rev. Financ. Stud. (2017).

${ }^{57}$ Azar et al., supra, at 37.

${ }^{58}$ Azar et al., supra, at 38.

${ }^{59} \mathrm{Id}$.

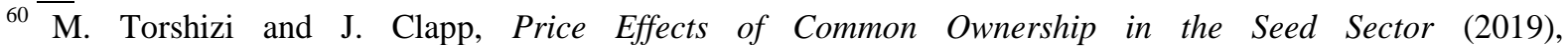
$<$ https://papers.ssrn.com/sol3/papers.cfm?abstract_id=3338485>.

${ }^{61}$ M. Backus, C. Conlon and M. Sinkinson, Common Ownership and Competition in the Ready-To-Eat Cereal Industry, (2018), faculty/searlecenter/events/antitrust/documents/sinkinson_cereal.pdf http://www.law.northwestern.edu/research-

${ }^{62}$ M. Newham, J. Seldeslachts and A. Banal-Estanol, Common Ownership and Market Entry: Evidence from Pharmaceutical Industry, (DIW Berlin, Discussion Paper No. 1738, 2018) .

${ }^{63}$ Backus et al., surpa at 20.
} 
500 firm valued a dollar of profits of another randomly chosen S\&P 500 component firm at 70 cents, which is more than triple that which its estimated value was in 1980. Although currently descriptive, these findings highlight a striking trend of divergence from the conventional assumption of profit maximisation, under which a typical S\&P 500 firm would place zero weight on a dollar of another firm's profits. In the same study, ${ }^{65}$ the authors found evidence suggestive of 'tunnelling', i.e. the practice of transferring profits (via acquisition, mispriced purchase orders or direct transfer) from one company to another in order to benefit the interests of a controlling stakeholder in both. ${ }^{66}$. Notably, the aforementioned study also highlights that these trends are not primarily associated with the recent rise of large investment funds, such as BlackRock and Vanguard, but by a broader rise in diversified investment strategies. $^{67}$

This also relates to the larger debate among economists about the steady increase in market power since the 1980s, with the average price level relative to marginal cost rising by nearly $1 \%$ p.a. ${ }^{68}$ These trends are linked to significant macroeconomic implications, such as the decrease in labour share, the increase in capital share, the decrease in low skill wages, the decrease in labour force participation, the decrease in labour flows, the decrease in migration rates and the slowdown in aggregate output.

The theoretical and empirical case for common ownership has been criticised. There were three types of criticism; these were directed at: (i) the appropriateness of the choice of measure of common ownership, (ii) the methods used to empirically estimate the effect of common ownership on prices, and (iii) the mechanism linking common ownership with reduced incentives to compete. It is easy to note that (i) and (ii) are methodological concerns that call for the improvement of models and estimation techniques, whereas (iii) casts doubt on the issue of common ownership per se. Some authors have highlighted that the anticompetitive mechanism does not have to be active, positing that institutional investors may employ "selective omission," in exercising their ownership rights. ${ }^{69}$ For a given firm, the "selective omission" mechanism implies pressing only for actions that increase the value of overall portfolio holdings while not pursuing actions that would be in conflict with the interests of the other firms in the portfolio. This strategy, the authors stress, has significant benefits compared to a 'targeted active' strategy, since it does not require the affirmative promotion of actions that reduce firm value.

As corporate governance practitioners highlight, ${ }^{70}$ it is important to have a precise understanding of the channel of the harmful effects that warrants regulation in order to avoid enacting overly damaging restrictions. Crucially, as this debate is ongoing and has become a

\footnotetext{
${ }^{64}$ M. Backus, C Conlon and M. Sinkinson, Common Ownership in America: 1980-2017, (National Bureau of Economic, Research Paper No. w25454, 2019).

${ }_{65}^{65} \underline{\text { Id. }}$

${ }^{66}$ S. Johnson, R. La Porta, F. Lopez-de-Silanes and A. Shleifer, Tunneling, 90(2) Am. Econ. Rev. 22-27 (2000).

${ }^{67}$ Backus et al., supra, at 64 .

${ }^{68}$ De Loecker and Eeckhout, supra, at 20.

${ }^{69}$ C. Hemphill and M. Kahan, The Strategies of Anticompetitive Common Ownership, (NYU Law and Economics, Research Paper No. 18-29 2018)

${ }^{70}$ F. Morton and H. Hovenkamp, Horizontal Shareholding and Antitrust Policy, 127 Yale Law J. 2026 (2017).
} 
more prevalent topic of discussion, new theoretical models ${ }^{71}$ and richer empirical evidence ${ }^{72}$ have emerged and are capable of addressing the above concerns. ${ }^{73}$ They model oligopolistic markets and define the parameters under which formally separate firms may behave as a single entity, with a specific focus on the internalisation and aggregation of shareholder objectives. ${ }^{74}$ In summary, although we agree with the need for further methodological improvements, we are not convinced by the arguments that try to do away with the issue itself. We explore these criticisms in detail in a separate study.

\section{Common Ownership and Coordinated Effects}

The current debate on common ownership primarily focuses on its short-run unilateral effects, thereby ignoring other important aspects of common ownership. The long-term time horizon of most investment funds implies repeated market interactions between the same set of firms and common owners. Such repeated interactions over a long period of time are recognised as having the potential to create favourable conditions for tacit collusion, however, the repetitive nature of these inter-firm interactions is, currently, not taken into account when conducting market regulatory assessments. This lack of consideration is all the more remarkable because these repetitive interactions, as opposed to one-off interactions, have the power to drastically change the equilibrium in and of markets. As Kreps states, ${ }^{75}$ one expects oligopolistic firms to collude as much as the relevant circumstances permit it to do so. In the following paragraphs we discuss the factors that either foster or hinder tacit collusion and the ways in which common ownership can contribute to them.

Tacit collusion arises from dynamic, repeated interaction between firms. Firms are able to set and maintain higher prices than they would in situations of market equilibrium. They do this by coordinating their activities so that such result in a higher price/lower output outcome and by tacitly agreeing that any deviation from the collusive course of conduct would trigger some form of retaliation to be imposed on the deviating firm. ${ }^{76}$

For illustrative purposes, consider a firm that is deciding whether to adhere to a collusive strategy or to deviate from it. One of the firms' first considerations will be that sticking with the collusive price strategy will allow it to receive its share of the future collusive profit, whereas deviating from such strategy will result in it initially reaping a greater profit in the short-term but such a period will be followed by a retaliation from

71 See J. Azar, Portfolio Diversification, Market Power, and the Theory of the Firm, (2017), <https://papers.ssrn.com/sol3/papers.cfm?abstract_id=2811221>; M. Anton, F. Ederer, M. Gine and M. Schmalz,_Common Ownership, Competition, and Top Management Incentives, 2-3 and 8-14 (Ross School of Business Paper No. 1328, 2018).

72 See A. Pawliczek and A. Skinner, Common Ownership and Voluntary Disclosure (2018), <https://ssrn.com/abstract=3002075>; J. Park, J. Sani. N. Shroff and H. White, Disclosure Incentives When Competing Firms Have Common Ownership (2018), <https://doi.org/10.1016/j.jacceco.2019.02.001>.

${ }^{73}$ E. Elhauge, How Horizontal Shareholding Harms Our Economy - And Why Antitrust Law Can Fix It (2019), <https://papers.ssrn.com/sol3/papers.cfm?abstract_id=3293822>, which provides a concicse summary.

${ }_{75}^{74}$ Azar, supra, at 71.

${ }_{75}^{75}$ D. Kreps, Game Theory and Economic Modelling (Oxford University Press, 1990).

${ }^{76}$ See E. Green and R. Porter, Non-Cooperative Collusion under Imperfect Price Information, Econometrica: J. Econ. Soc. 87-100 (1984); M. Ivaldi, B. Jullien, P. Rey, P. Seabright and J. Tirole, The Economics of Tacit

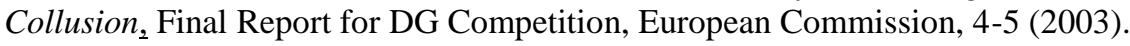


competitors and, thus, it will only benefit from normal or reduced profits in future. Therefore, the ability of a firm to collude with other firms depends on its (i.e. the firm's) objectives and the relative importance to it of its current profits compared to its future profits and its discount factor. Collusion is sustainable if, and only if, firms give sufficient weight to their future profits, i.e. if their discount factor is not too small. Conversely, if the discount factor is below this threshold, collusion is not sustainable and competition will induce firms to consistently price at cost.

Common ownership can potentially introduce more transparency into the market and, thereby, facilitate collusion. It is suggested that common owners can (or have the potential), to some extent, better observe the market strategies pursued by and outcomes that result for the individual firms into which they invest. This, in turn, can allow for a lower trigger threshold and increase the attractiveness of collusion. Structural links can facilitate collusion by (i) reducing the gains firms may make from undercutting their rivals and, (ii) by creating more possibilities for retaliation/punishment. He and Huang show that institutional crossownership of same-industry firms facilitates explicit forms of product market collaboration, such as within-industry joint ventures, strategic alliances and/or within-industry acquisitions. ${ }^{77}$ Gilo, Moshe and Spiegel show that partial cross-ownership reduces the gains acquired from deviating from the collusive equilibrium, provided there is a sufficiently longrun interaction and sufficiently forward-looking players. ${ }^{78}$ There is currently an argument as to whether the same logic may apply to common ownership. As previously discussed, investment funds are considered to have a more long-term focus than other investors in the market. Firms present in and on several markets are known for being able to sustain collusion more easily than firms only present in one market. ${ }^{79}$

It is important to note that there are practices that, although they do produce anticompetitive effects, are not considered to be unlawful in specific circumstances. For instance, both Article 101 of the Treaty on the Functioning of the European Union ('TFEU') and Section 1 of the Sherman Antitrust Act 1890 consider 'conscious parallelism' to be acceptable. This concept relates to the situation in which one firm takes a leading role in raising the price of a product and other firms follow, i.e. they also raise the price of their product, without there being any explicit agreement between all the firms involved. This is distinct from tacit collusion, which constitutes a violation of competition law. Tacit collusion occurs when firms act against their own economic interest, i.e. they act in the interest of their competitors. Regulators distinguish conscious parallelism from tacit collusion by considering whether the relevant firms have exchanged information between themselves and whether they have provided each other with advance notice of their intended price changes. As discussed above, a higher level of information transparency is a factor that is likely to be present involving a high concentration of common ownership. As Ginsburg and Clovers point out "common ownership [in and of] itself does not facilitate collusion; rather, at worst, it may facilitate practices that are themselves facilitating practices, such as information

\footnotetext{
${ }_{77}^{7}$ J. He and J. Huang, supra, at 56.

${ }^{78}$ Gilo et al., supra, at 35, 81-99.

${ }^{79}$ B. Bernheim and M. Whinston, Multimarket Contact and Collusive Behaviour, RAND J. Econ. 1-26 (1990)
} 
exchanges" ${ }^{\prime 80}$. This may, however, constitute a problem for competition policy decisionmakers that take a precautionary approach in order to limit the risk of anti-competitive collusion. One may also note that jurisdictions may prefer to adopt a prophylactic approach they may seek to develop specific prohibitions and rules concerning facilitating practices and to extend the scope of competition scrutiny concerning oligopolistic structures so that such also covers unilateral conduct, e.g. invitations to collude amongst other practices that facilitate tacit collusion. Indeed, section 5 of the Federal Trade Commission Act ('FTC') 1914 provides such a tool. Many arguments have also been made in favour of re-interpreting section 1 of the Sherman Antitrust Act 1890 so that it covers situations of tacit collusion that have arisen without there being any communication but these arguments have not yet been accepted by the US courts. It is important to note here that there is no equivalent provision to section 5 of the FTC Act in EU competition law.

However, there is also evidence that whenever a common owner acquires a stake in the firm it increases both the stake of collusive profit and the asymmetry between integrated and unintegrated competitors. This collusion-enhancing effect may also be observed in situations of vertical integration. In analysing the effect of mergers in vertically integrated markets, Biancini and Ettinger show that vertical integration generally favours collusion. ${ }^{81}$ Hence, there is a need to explore the same collusive effects in relation to vertical integration at the level of common owners.

\section{Common Ownership and Vertical Effects}

In addition to the horizontal unilateral and/or co-ordinated concerns that may arise out of common ownership by financial investors, one needs to also examine the risks of anticompetitive foreclosure strategies that affect horizontal competition between undertakings controlled or influenced by common owners vis-a-vis undertakings on which common owners do not exercise any control or influence. The presence of the same financial investors in all concentrated segments of the FVC may incentivise practices of vertical foreclosure if these serve to increase the profits of the common owners. This is a plausible assumption that institutional investors seek to maximise the net value of their entire portfolio rather than just the value of one, individual firm in which they have invested. As Schmalz explains, "shareholder-value maximising firms should internalise all types of externalities they impose on other firms that are horizontally or vertically connected or otherwise mutually affecting each other, to the extent that their influential shareholders hold shares in these other firms". ${ }^{82}$ A similar point is put forward by Romano, who observes the complex inter-market dynamics created by common ownership, including those generated in vertically-related markets in which institutional investors may also be present, and argues for developing policies that take

\footnotetext{
${ }^{80}$ D. Ginsburg and K. Klovers, Common Sense About Common Ownership, (George Mason Law and Economics, Research Paper No. 18-09, 2018) .

${ }^{81}$ S. Biancini and D. Ettinger, Vertical Integration and Downstream Collusion, 53 Int. J. Ind.Organ. 99-113 (2017) .

${ }^{82}$ Schmalz, supra, at 19, 417.
} 
into consideration these 'inter-market spillovers' ${ }^{83}$ These 'input-output linkages' that may exist between the different segments of the FVC may be a factor that serves to complicate analysis concerning the incentives of common owners and the welfare effects of common ownership. ${ }^{84}$ Freeman has recently argued that common ownership, in the context of a supply chain, may provide a simpler, less expensive and arguably less restrictive alternative to competition than vertical integration. He also argued that such would align supply chain goals, to the extent that a high level of common ownership "would create or solidify the commonality of the firms' economic (customer and supplier) goals". ${ }^{85}$ Freeman puts forward the traditional efficiencies of vertical integration brought by common ownership by explaining that it strengthens the supply relationship without imposing the higher costs of a direct equity stake providing control by one party to the other. These pertain to the traditional benefits put forward by transaction cost economics, such as lower transaction costs through improved governance mechanism, the avoidance of ex post opportunism that comes out of investment in relation-specific assets, better financial cooperation within the supply chain, benefits relating to the improvement of innovation and a better combination of innovation assets and knowledge exchange throughout the vertical chain. ${ }^{86}$ Although these positive effects should certainly be considered on a case-by-case basis, it is also important to take into account the anti-competitive effects of this vertical integration through common ownership with particular regard to the possible adoption of anti-competitive foreclosure strategies. In the first sub-section below (i), we examine the practice of margin squeeze and use it to illustrate the anticompetitive foreclosure effects of common ownership in a vertical context.

However, the risk of anticompetitive foreclosure is not the only issue that may emerge from common ownership in a vertical relationship. As we will examine in (ii), the FVC is characterised by the existence of various concentrated segments within which the presence of the same institutional investors is increasing and, thus, the FVC is characterised by situations of vertical common ownership. However, it should be noted that is not so for the farming segment, which is still characterised by a market structure close to that of atomistic competition with comparatively little involvement of institutional investors. This specific configuration, which may be unique to the FVC, may accentuate the incentives of common owners to restrict vertical competition, i.e. competition between the various segments of the FVC for a larger share of the total surplus value produced by it, and to adopt strategies that increase their profits to the detriment of the farming segment of the FVC. Contrary to the previous scenario of vertical integration, in which the common owners are present at two or more vertically adjacent segments, in this configuration (the vertical common ownership configuration) common owners will be present upstream or downstream the farming segment of the FVC. Hence, the traditional benefits of vertical integration and/or the traditional vertical foreclosure theory of harm may not be applicable in this context. However, such configuration may provide incentives for practices that reduce the margins of farming

\footnotetext{
83 A. Romano, Horizontal Shareholding: The End of Markets and the Rise of Networks, 5 (2018), <https://papers.ssrn.com/sol3/papers.cfm?abstract_id=3255948>.

${ }^{84}$ Id. 16.

${ }_{85} \frac{\mathrm{K}}{\mathrm{K}}$. Freeman, The Effects of Common Ownership on Customer-Supplier Relationships, 5 and 7 (Kelley School of Business, Research Paper No. 16-84, 2018).

${ }^{86}$ Id. 3 and 6.
} 
segment, the only segment of the FVC that is not overly concentrated. This exploitation of market power upstream and downstream can have a considerably effect on the capability of the farming segment to gain rewards for its productivity and, thus, in turn, also have an effect on incentives to innovate in this sector. Hence, in addition to the more traditional vertical foreclosure concerns, common ownership may also raise vertical exploitation concerns that could be of relevance for competition law enforcement. These concerns are examined in (ii). Furthermore, the financialisation of the FVC may have broad implications on the profit margins of the segments of the FVC that have either been financialised to a lower degree or not at all, which may, in turn, result in negative ramifications as to the overall productivity of the food sector and the balance of power between the various segments of the FVC. These are explored in (iii).

\section{(i) Anti-Competitive Foreclosure Concerns}

One may compare the anti-competitive foreclosure concerns raised by common ownership across the value chain with some of the concerns expressed in the context of partial vertical integration. Under partial integration, the loss is borne by non-integrated shareholders. ${ }^{87}$ For example, if firm $\mathrm{U}_{1}$ (upstream) only sells to firm $\mathrm{D}_{1}$ (downstream), this allows firm $\mathrm{D}_{1}$ to make higher profits than its rivals. Firm $\mathrm{U}_{1}$, in this case, makes lower profits because it could have sold to other downstream firms. Shareholders who cross-own both firms share the profits of both and are better off, as long as the shared profits are higher than pre-foreclosure profits of both. The remaining (non-integrated) shareholders of firm $U_{1}$ effectively subsidise the foreclosure profits (note that the remaining shareholders of firm $\mathrm{D}_{1}$ are also subsidised). The same arguments on information transparency that were laid out in the previous section apply here. Monopoly profits are less likely to be sustained under asymmetric information conditions - a firm would not buy under a monopoly price if they suspect that their competitor may be getting the same supply at a lower price. When firms are integrated their profits are linked and the upstream firm would not sell to a downstream competitor as it would be deliberately inflicting a loss on its integrated downstream firm.

In sum, vertical integration can enhance efficiency by reducing double marginalisation and increasing carriage of channels. Equally, though vertical integration can also harm welfare due to incentives to foreclose and/or raise rivals' costs. In line with this theoretical argument, Fiocco considers 'passive partial forward integration' and shows that it allows the manufacturer to capture some of the information rents that accrue to a privately informed retailer and, hence, affects the contracts that the manufacturer offers the retailer and the resulting competition in the downstream market. ${ }^{88}$ Höffler and Kranz consider 'passive partial backward integration, ${ }^{89}$. In their model, the (regulated) upstream supplier may internalise some of the downstream profits and, consequently, sabotage the access of rival downstream firms to its essential input. Thus, on the vertical level, common ownership

\footnotetext{
${ }^{87}$ N. Levy, Y. Spiegel and D. Gilo, Partial Vertical Integration, Ownership Structure and Foreclosure, 10(1) Am. Econ. J-Microecon. 132 (2018) .

${ }^{88}$ R. Fiocco, The Strategic Value of Partial Vertical Integration, 89 Europ. Econ. Rev., 284 (2016) .

${ }^{89}$ F. Höffler \& S. Kranz, Imperfect legal unbundling of monopolistic bottlenecks, 39 J. Regul. Econ. 273 (2011); F. Höffler \& S. Kranz, Legal unbundling can be a golden mean between vertical integration and ownership separation, 29 International J. Ind. Organ. 576 (2011).
} 
presents potentially even greater anti-competitive concerns if the same owners are present in several markets of the value chain.

Similarly, Hunold, Röller and Stahl show that passive backwards ownership leads to an increase in downstream prices. ${ }^{90}$ As discussed above, full vertical integration can lead to a decrease in prices through an increased efficiency. Hence, these authors argue that downstream acquirers strategically abstain from vertical control, thereby inducing an efficient supplier to commit to high prices. ${ }^{91}$ They also show that even when more general pricing schemes, such as two-part tariffs, are admitted to the model, backwards ownership still leads to an increase in downstream prices, which, in turn, harms consumer welfare.

The ability to implement a strategy based on foreclosing competitors from the target company's supply or demand depends on the influence that results from the minority shareholding over the business decisions of the target company and on the ability to successfully exercise this influence over other stakeholders. Extensive information rights can also matter in this regard - the fear that commercially sensitive information may end up in the hands of a competitor may deter companies from dealing with firms in which their competitors have minority stakes. In cases where the minority shareholding is purely 'passive' and its holder has no influence on the target firm's decisions, the potential competition concerns will be more limited than they would be in a full merger, given the lesser financial incentives to foreclose. Conversely, in cases where the minority shareholding is 'active' and its holder has some influence on the target firm's decisions, the risk of foreclosure is higher. Input or customer foreclosure may be more likely to occur because the company acquiring the minority shareholding will only internalise a part, rather than all, of the target firm's costs while it will receive the full benefit of upstream and downstream foreclosure. Undiversified shareholders who wish to maximise the value of their holding in one segment of the value chain would also, particularly when compared with the context of horizontal common ownership, have fewer incentives to oppose these foreclosure strategies to the extent that such practices may increase their own firm's profits and, therefore, correspond to their interest.

The Organisation for Economic Co-operation and Development ('OECD') recommends that authorities consider the following. "What types of investors tend to own shares across multiple competing firms in a market? For example, are they predominantly passive investors or do investors with active investment strategies also pursue such shareholdings? Do they also exhibit vertically-diversified shareholdings?" They also suggest considering whether "institutional investors have the capacity to evaluate whether a decision by a portfolio firm will improve or worsen the value of their portfolio, taking into consideration their horizontal and vertical holdings?"

Anti-competitive foreclosure may involve vertical foreclosure. This arises when "the bottleneck good is either used as an input by a potentially competitive downstream industry (i.e. 'input foreclosure') ... or when the bottleneck is needed to access final consumers (i.e.

\footnotetext{
${ }^{90}$ M. Hunold, L.-H. Röller and K. Stahl, Backwards Integration and Strategic Delegation, (ZEW-Centre for European Economic, Research Discussion Paper 12-022, 2012).

${ }^{91} \mathrm{Id}$.

92 OECD, Common Ownership by Institutional Investors and its Impact on Competition Background, Background Note by the Secretariat, DAF.COMP(2017)10 (2017).
} 
'customer foreclosure')". ${ }^{93}$ It is equally possible that anti-competitive foreclosure may comprise horizontal foreclosure. This "arises when the monopolised good is sold directly to the customer, who uses it in conjunction with complementary goods (e.g. system goods or after-sale services)". It involves scenarios in which the integrated undertaking attempts to protect its upstream monopoly or core market from potential competition from downstream customers or protect its market position in an adjacent market. Although most of the scenarios concerning margin squeeze that have been examined by the EU and national competition authorities and courts involved vertical foreclosure as "margin squeeze allegations are typically made in network industries where a vertically integrated operator supplies access to its network to downstream competitors", one cannot exclude the possibility of margin squeeze also involving horizontal foreclosure. The horizontal foreclosure argument will often be based on the 'maintenance of monopoly' theory of harm or that of 'defensive leveraging'.

Vertical foreclosure may involve the theory of harm based on leveraging, with the main anti-competitive motive being to either monopolise the downstream market or dampen competition in it. The vertical foreclosure theory was criticised by the Chicago school of antitrust economics. It argued that there is only one single monopoly profit to be made from the entirety of the vertically integrated structure and that the bottleneck monopolist may earn the entire monopoly profit simply by charging the monopoly margin at the upstream (bottleneck input) level. Consequently, leveraging market power from the bottleneck input market to the downstream market is not the main rationale for adopting such practices, and that these may be explained by efficiency reasons. The 'single monopoly profit' theory was criticised by post-Chicago antitrust economists, who contended that such could only occur in very limited conditions and that in the absence of exclusionary practices the upstream monopolist cannot fully exert its monopoly power.

Competition at a single market in the value chain (i.e. 'horizontal competition') can be reduced if upstream suppliers can raise input prices or limit input sales to their horizontal rivals (without overlapping financial investor ownership), or if downstream customers restrict their purchases from horizontal rivals (without overlapping financial investor ownership). For instance, the margins of the only segment of the FVC with a market structure that resembles atomistic competition and in which institutional investors have a lesser presence may be squeezed by the undertakings present in the upstream input markets or the downstream processing markets in which these institutional investors have a more significant presence (see (ii) below).

From an economic perspective, anti-competitive foreclosure in the FVC may result from exclusionary strategies, such as margin squeeze. Margin squeeze supposes the existence of a vertically-integrated firm with a dominant position in an upstream market, which it uses to prevent its (non-vertically integrated) rival in a downstream market from achieving "an economically viable price-cost margin"94 (see Figure 1).

\footnotetext{
${ }^{93}$ B. Jullien, P. Rey and C. Saavedra, The Economics of Margin Squeeze, Report of the Institut D'Economie Industrielle 11 (2014).

${ }^{94}$ R. O'Donoghue and J. Padilla, The Law and Economics of Article 102 TFEU 366 (Hart Publishing, $2^{\text {nd }}$ ed, 2013),.
} 
Figure 1: Classic Market Structure in which Margin Squeeze May Arise ${ }^{95}$

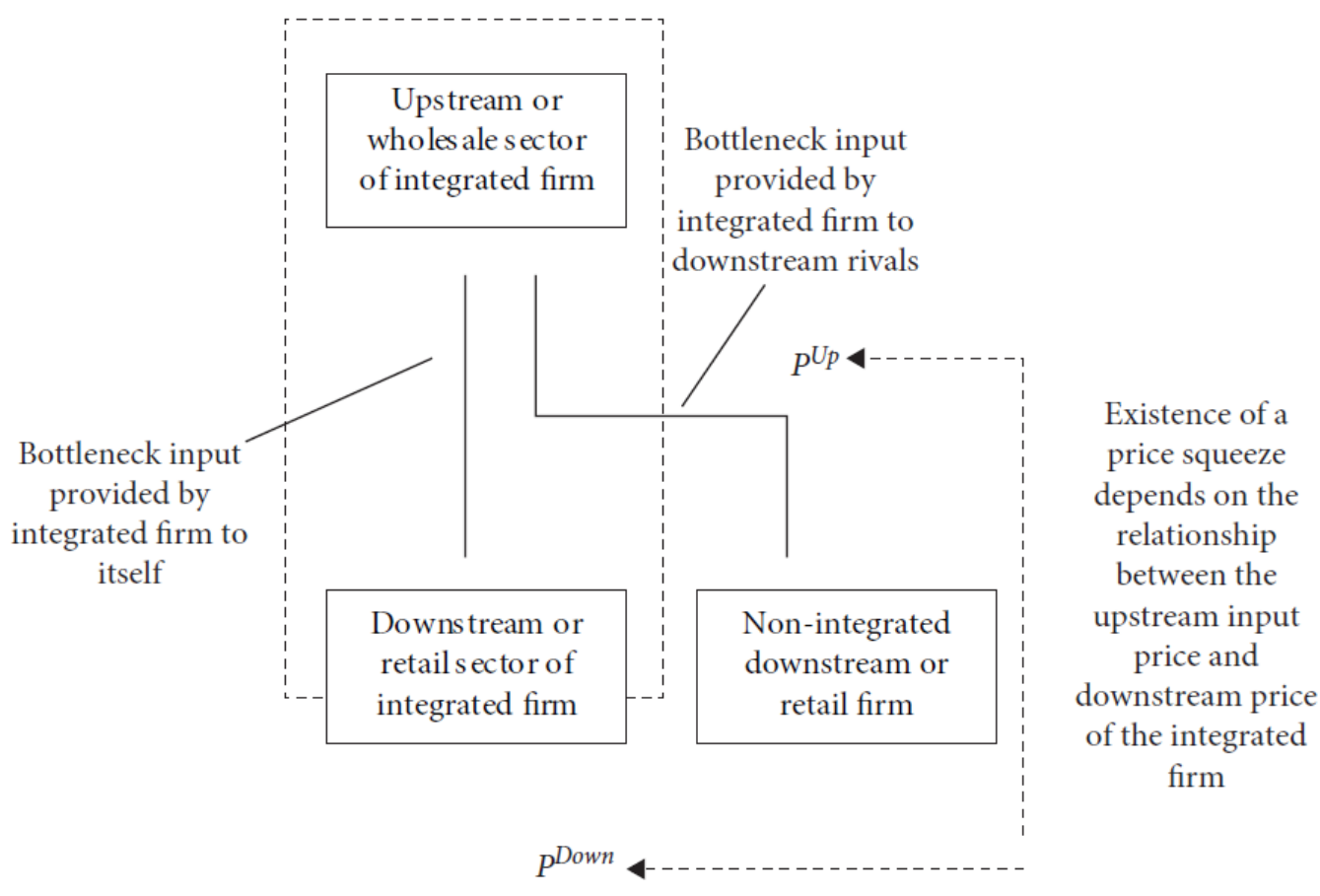

Economists have identified different rationales/theories of harm that underlie anticompetitive margin squeeze. One rationale/theory is that margin squeeze is the result of an exclusionary practice, either that of 'predatory pricing' or 'anti-competitive foreclosure'. Predation would be the relevant theory of harm in situations in which the relevant firm is sacrificing its profits, by charging its product at a price that undercuts that of its rivals, in the first time phase (for however long that phase may be) but then recouping such in the second time phase (for however long that phase may be). When considering whether a predatory pricing theory of harm is applicable, the relevant competition authority or court would need to examine "whether the dominant firm's own downstream business would be profitable if it had to pay the same actual input prices as third parties". 96 The focus here would be on the analysis of downstream competition between the dominant undertaking and its competitor(s), on which the specific common owner present in the shareholding of the dominant undertaking upstream is not present or its presence is insignificant.

There are, however, notable differences between margin squeeze and predatory pricing. One key difference is the fact that margin squeeze does not require the dominant undertaking to be suffering a net loss. The dominant undertaking might be able to gain profits upstream rather than downstream and, thus, the margin squeeze may overall be profitable for the vertically integrated undertaking. In the case of vertical common ownership, it is important to analyse whether the practice would be profitable for shareholders with diversified portfolios. To do so, it is necessary to take into account both the negative and positive spillovers resulting from the practice. In relation to the former type of spillover, it is

\footnotetext{
95 OECD, Margin Squeeze, Policy Roundtables DAF/COMP(2009)36 25 (2009).

${ }^{96}$ O’Donoghue and Padilla, supra, at 92, 397.
} 
necessary to consider the impact the practice may have on firms in the vertically-related markets in which the shareholders with diversified portfolios have stakes. In relation to the latter type of spillover, it is necessary to consider the impact of the practice on other firms in the portfolio of the horizontal shareholders, due to higher prices in the upstream market. Hence, contrary to predation strategies, it is not necessary to examine the recoupment of this 'sacrifice' by the dominant undertaking; it may well be that the undertaking recoups its losses, more or less, simultaneously during the period of margin squeeze. ${ }^{97}$ The existence of a 'sacrifice' in margin squeeze cases may, however, take different forms, such as the opportunity cost for each unit not sold to downstream competitors because of the high price of the bottleneck input, this opportunity cost sometimes being quite high if the wholesale price is above the upstream marginal cost (e.g. in the presence of large economies of scale). However, to the extent that the diversified shareholders do not suffer the full scale of these costs, as the most significant part of them is incurred by the undiversified shareholders of the firms in the downstream market, they may see their upstream profits increase considerably due to the higher prices in the upstream market and these potential upstream gains may outweigh any negative spillovers in the downstream market. In combination with upstream horizontal ownership, vertical common ownership may incentivise firms to pursue strategies like that of margin squeeze or other exclusionary strategies. Adopting such strategies would not require the 'active' engagement in governance of the common shareholders, as adopting vertical foreclosure strategies would be profitable at the upstream firm level, and not just at the portfolio level, and would therefore be situated within the managerial incentive. It is also likely that it would not be opposed by undiversified, upstream shareholders in view of the potential overall gains and the fact that it may increase their own firms' profits to a greater degree than that which could have be achieved had there been an aggressive change of control. $^{98}$

By raising its upstream price, the bottleneck monopolist may have the power to reduce the profits earned by downstream competitors. In doing such, the upstream monopolist is effectively capturing the profits that would have come to its downstream competitors for itself - this is known as the 'excessive pricing' theory of harm. It should be noted though that the upstream monopolist should never charge too high a price else it will eliminate its downstream rivals and, in doing so, will eliminate the wholesale profits it the upstream monopolist) makes by selling the bottleneck input to them. As a vertically integrated undertaking derives its revenue from two sources: the wholesale level and the retail level, it needs to ensure that both continue to exist. When firms operating at different levels of the chain are integrated, their profits are linked and, thus, an upstream firm will not sell its product to a downstream competitor as doing so would inflict a loss upon the downstream firm with which it has integrated its operations.

However, this strategy makes sense when a vertically integrated firm's downstream rivals are differentiated from its own downstream unit. For example, downstream rivals may operate in a niche market segment or may offer better customer service, which may give them

\footnotetext{
${ }^{97}$ Id. 398.

98 For a similar point in the context of horizontal common ownership and possible unilateral effects, see Schmalz, supra, at 19, 420.
} 
the opportunity to sell the product at a higher price than that which the vertically integrated firm's own downstream unit can charge. Exploitative wholesale pricing may reduce the competitiveness of downstream competitors, thereby providing the monopolist with a "price umbrella" under which the monopolist can raise prices at the downstream level or increase the profits of its downstream unit, which is known as the 'raising rivals' costs' theory.

Margin squeeze claims involve some profitability analysis. This "entails assessing whether the vertically integrated dominant firm's own downstream operations could operate profitably on the basis of the upstream price charged to its competitors by its upstream operating arm". 99 This is performed either by employing a "period-by-period" approach, which involves assessing whether the vertically integrated, dominant firm's own downstream operations could operate profitably on the basis of the upstream price discounted cash flow ('DCF') approach. Similar assessments would need to be made in order to identify the spillover effects that may result from vertical foreclosure practices on the profits of the portfolios of institutional investors in order to understand their incentives to support such strategies. The question whether such foreclosure can be fuelled by the presence of institutional investors in most segments of the value chain is yet to be explored.

Despite these anti-competitive harm narratives, economists acknowledge that margin squeeze may generate efficiency gains, such as dynamic pricing in markets with network effects and switching costs, promotional efforts for experience goods or credence goods, emergent markets, or pursuing such conduct in order to better compete. Also, it is often argued that there is a high likelihood of erroneously identifying conduct that seems to be margin squeeze but is, in fact, not. This is because it is highly possible that the relevant competition authorities and/or courts may fail to take into account other possible justifications for downstream costs exceeding the difference between upstream and downstream prices; these justifications may be things like industry shakeouts, temporary responses to bad market conditions, or the fact that a company has undertaken legitimate investments in order to enhance its future profitability. Hence, efficiency gains should, and arguably need to, be factored into the analysis.

\section{(ii) Vertical Exploitation Concerns}

One could also focus on the vertical exploitation that may result from a restriction of vertical competition in relation to the total surplus value produced by the FVC. As the farming level is competitive, with little to no presence of institutional investors, it is possible that diversified shareholders present in the upstream to the farming segment input markets and/or the downstream processing markets may adopt strategies that seek to redirect the value created within the FVC away from the farming segment. This could be achieved through the imposition of 'unfair' contract terms. The objective pursued would be different from that of margin squeeze, which would be conducive to vertical foreclosure. Rather, vertical exploitation involves the extraction/capture of a higher share of the joint profit resulting from co-operation between the different segments of the FVC rather than excluding an upstream or downstream competitor. Nevertheless, the ultimate objective of such conduct could still be to

\footnotetext{
${ }^{99}$ Id. 6
} 
impede the 'upgrading' of value chain participants, thereby preserving the bargaining power of firms operating in the upstream inputs segment of the FVC or in the downstream processing segments. Financial investors may rely on their common ownership in and/or of the other segments of the value chain, particularly the factors of production and processing, in order to extract this (potential) additional revenue and marginalise vertical competition from the farming segment, which is the least concentrated segment of the FVC. This may negatively affect the profitability of farming. It may also have a negative impact upon the ability and incentive of firms operating in the farming sector to invest in research and development ('R\&D') and increase their productivity. Exploitation of upstream/ downstream market power by firms, in which the institutional investors have a presence, will squeeze the margins of the farming segment. In turn, this will increase the economic and technological dependence of the farming segment, particularly those aspects of it which are competitive, on the upstream inputs markets and downstream processing and/or retailing markets, all of which are concentrated segments.

For instance, an upstream oligopoly operating in the inputs segment of the FVC, segments in which institutional investors have a significant presence, could raise prices above the competitive level in order to appropriate some of the value created by the downstream farming segment. Contrary to the anti-competitive foreclosure scenario examined in the previous section, to the extent that these institutional investors are not present in the farming segment, they will not face any conflicts of interest. Hence, such conduct will not have any negative spillovers on the value of their portfolio.

However, the aforementioned oligopoly has to be wary of not charging too high prices as such would serve to eliminate firms downstream. If the oligopoly were to pursue such conduct, this course of action would likely reduce their profits in the wholesale market of inputs. This is because the increased level of concentration in the farming segment, which would have resulted from reducing the number of farming units, may reduce their (i.e. the oligopoly's) bargaining power in imposing contract terms that are advantageous to it but are unfair to the farming level.

Nevertheless, such exploitative practices may work if upstream firms set prices at a level that would keep the farming segment afloat while, simultaneously, permitting them to capture most of the surplus value produced by the FVC. The farming sector may indeed receive support from the state through direct or indirect payments or from preferential loans, which would enable firms in this segment to continue despite their reduced profitability. Furthermore, farmers, if given some form of competition law immunity, may be given the option of collectively negotiating with the upstream firms selling inputs.

By reducing the bargaining power of the farming segment, the upstream oligopoly would be able to reinforce the "threat points" upon which it may rely in negotiations, thus, negatively affecting the ability of farmers to seek the best alternative to the negotiated agreement ('BATNA'). The difference in bargaining power between the parties frequently results in unfair contractual terms and serves to reinforce the structural inequality between them with the competitive farming segment coming off worse.

A similar strategy may be adopted by a monopolist or oligopolists operating in the downstream processing segment. The substantial presence of institutional investors enables 
firms in this heavily concentrated segment of the FVC to exercise buying power vis-a-vis the farming segment, thereby squeezing the latter's margin to an even greater degree. Due to the structural inequality and weaker bargaining position from which farmers suffer, the extent to which they can appropriate rewards for their investments in improving productivity is severely limited. In turn, this affects both the level of innovative developments they undertake and their overall incentives. Thus, farmers are truly between a rock and a hard place; the rock of the concentrated upstream segment of the FVC and the hard place of the equally concentrated downstream segment of food processing, both of which are characterised by $t$ increasing presence of the same institutional investors.

The presence of institutional investors in adjacent markets to the farming segment provides them with information as to the cost of farming and enables them to capture information rents. This serves to accentuate the asymmetrical bargaining positions of the farmers as opposed to the input or processing oligopolists/ monopolists. As was previously explained, a passive partial forward integration may enable the manufacturer to capture some of the information rents that accrue to privately informed retailers and, hence, may affect the terms of the contract offered by the manufacturer to the retailer, which, in turn, may affect the state competition in the downstream market. ${ }^{100}$ Furthermore, Splenger shows that the surcharges imposed in vertically integrated markets are driven by the presence of a sufficient level of horizontal integration at different individual stages. ${ }^{101} \mathrm{He}$ argues that vertical integration, which in and of itself has the potential to benefit both consumers and producers, of the unintegrated stages of production may enable a higher-stage producer to evade the 'monopolistic' surcharges imposed by the suppliers at lower stages. With a specific focus on manufacturing and retailing sectors, Corniere and Taylor present the case of upstream bundling enabling profitable leverage by reducing rivals' willingness to pay slotting fees. ${ }^{102}$ If consumers value one-stop shopping, the bundling of components/products by an upstream manufacturer enables the downstream retailer to stock more units/products, which, in turn, will make the relevant retailer more attractive to customers.

In conclusion, if the same owners are present in several of the markets comprising the FVC, common ownership, on the vertical level, presents potentially very significant anticompetitive concerns. As more reliable evidence has emerged from cross-industry studies, ${ }^{103}$ as opposed to market-level studies, it is evident that there is a growing need to focus on anticompetitive market structures in general, rather than on the specific causal mechanisms that reduce competition within a single market. ${ }^{104}$

One may understand vertical competition between various segments of the FVC as being less concerned about the rents gained in various product markets and more about being a key factor in enabling the firms operating in the segment in question to reshape the

\footnotetext{
${ }^{100}$ Fiocco, supra, at 88, 284-302.

${ }^{101}$ J. Spengler, Vertical Integration and Antitrust Policy, 58(4) J. Polit. Econ. 347-352 (1950).

102 A. De Cornière and G. Taylor, Upstream Bundling and Leverage of Market Power, www.ssrn.com (2018), https://papers.ssrn.com/sol3/papers.cfm?abstract_id=3222597.

${ }^{103}$ See Anton et al., supra, 70, 2-3 and 8-14; G. Gutiérrez and T. Philippon, Investmentless Growth: An Empirical Investigation, 89, 91, 95-101 and 123-125 (Brookings Papers On Economic Activity, 2017).

104 E. Elhauge, The Causal Mechanisms of Horizontal Shareholding (2019), <https://papers.ssrn.com/sol3/papers.cfm?abstract_id=3370675>.
} 
'industry architecture' to their own advantage. The concept of 'industry architecture' stems from Teece's seminal contribution on how profits from innovation and various governance arrangements between the innovator and other vertically-related firms may influence the distribution of these innovation gains. ${ }^{105}$ Jacobides explains that "industry architecture provides the contours and framework within which actors interact: they are usually partly designed (by regulation or by de facto standards) and partly emergent (from the creation of socially understood templates and means to coordinate economic activities)". ${ }^{106}$ By looking to a value chain, one may observe the emergence of 'winners' who strive to frame the industry architecture to their own advantage by developing complex strategies. The objective of these strategies is to capture a disproportionate amount of the surplus value created by innovation. Recognising that the majority of the value generated by innovation is harvested in the financial markets makes it easier to understand the way in which the architecture of industry architecture is geared in favour of some specific segments of the value chain, to the detriment of others. This preference/bias displayed by the architecture has the potential to affect the percentage of the sector's total market capitalisation and, therefore, the surplus value captured by each segment of the value chain. Many factors could influence industry architecture as demonstrated by references in the literature to technological path dependence and the prevailing regulatory framework among other factors listed. The significant presence of institutional investors in all but the farming segment of the FVC may constitute an additional factor. Such factor may prove capable of influencing the industry architecture in this sector and leads to the weak, from a structural perspective, position of the farming segment vis-à-vis other segments of the food value chain.

\section{(iii) Financialisation of the Food Value Chain and Vertical Competition}

In addition to the possibilities of vertical common ownership producing anticompetitive effects, which have been explored in previous sub-sections, some studies have linked the general financialisation of markets with the shifting balance of power and, consequently, with the shifts of profit margins between industries. Specifically for the food industry, Isakson argues that the financialisation of the food markets has led to (i) the rise of food retailers as the dominant actors on the market, (ii) the central role of finance capital in 'dictating' the activity of food retailers, (iii) the exploitation of food workers, in particular a reduction of their wages, and (iv) a negative impact on small-scale farmers since they operate in the segment that remains most vulnerable to market volatility. ${ }^{107}$ Indeed, the incentives that the financialised segments create for the downstream segments render it economically nonfeasible for farmers to avoid interacting with them, while at the same time, the costs of this financialisation process have (arguably) been passed on to the farmers ${ }^{108}$, eventually leading to a rise of their indebtedness. We explore financialisation in various segments of the food

\footnotetext{
${ }^{105}$ D. Teece, Profiting from Technological Innovation: Implications for Integration, Collaboration, Licensing and Public Policy, 15(6) Res. Policy 285 (1986).

${ }^{106}$ M. Jacobides, T. Knudsen and M. Augier, Benefiting from Innovation: Value Creation, Value Appropriation and the Role of Industry Architectures, 35 Res. Policy 1203 (2006).

${ }^{107}$ S. Isakson, Food and Finance: The Financial Transformation of Agro-Food Supply Chains, 41(5) J. Peasant Stud. 749-775 (2014).

${ }^{108}$ Id.
} 
value chain

Food Retailing - Retailers provide an inventory management model, which is attractive for downstream clients. The model is based on low demand being placed on funds for inventory and storage. It also allows for payment to the relevant supplying farmers to be delayed by 1-3 months and this delay serves to free up these funds for financial activities in the short-term that benefit shareholders. Furthermore, the cost of providing this attractive model is shifted from the retailers on to the farmers - the latter is placed in the position of receiving late payments whilst, simultaneously, having to comply with the "just in time" demand in relation to inventory.

Agricultural Risk - Similar patterns are observed in regard to the market for agricultural risk. Bush develops an interesting argument which centres on the notion that the expectations created by the speculative derivatives market increase the volatility of the real market, which, in turn, directly affects farmers operating on a smaller-scale and makes it more expensive for farmers to hedge their risks. ${ }^{109}$

Food Trade and Processing - Murphy, Burch and Clapp highlight how food retailers are increasingly engaged in a variety of financial activities in which they can leverage their first-hand knowledge of market conditions in order to drive up profits for their clients. ${ }^{110}$ They provide the example of the world's four largest grain traders - Archer Daniels Midland (ADM), Bunge, Cargill and Louis Dreyfus (or, as they are collectively referred to, the 'ABCDs') - and dhow that the ABCDs all provide established investment vehicles to their external investors that permit them to speculate on agricultural commodities and other dimensions of food production. They state that "due to their [the ABCDs'] dominance of agricultural trade and their direct contact with food suppliers, the ABCDs are among the first to know about supply conditions, making their financial products particularly attractive to investors wishing to speculate on agricultural derivatives markets. Indeed, Louis Dreyfus' hedge fund, the Alpha Fund, which operates under the slogan 'monetise our expertise', has expanded rapidly, growing some 20-fold within its first two years and, ultimately, refusing to accept new investors because the fund had grown so large after a mere three years of operation".

Given how profitable such hedge funds have proven to be, Meyer argues that the incentives in the market are currently shifting from the actual products to catering to speculators' interest in price movements. ${ }^{111}$

Agricultural Inputs and Land - Market segments that produce inputs, such as land, seeds, fertilisers and machinery have seen an increasing influx of investors over recent years. ${ }^{112}$ Although there has been a lack of investigation into the 'price-cost squeeze' in this segment, it has been argued that entry of investors into this segment has been associated with

${ }^{109}$ S. Bush, Derivatives and Development: A Political Economy of Global Finance, Farming and Poverty, (Palgrave Macmillan, 2012).

${ }^{110}$ S. Murphy, D. Burch and J. Clapp, Cereal Secrets: The World's Largest Grain Traders and Global Agriculture, Oxfam Research Reports (2012).

${ }^{111}$ J. Mayer, The Growing Interdependence Between Financial and Commodity Markets, (United Nations Trade and Development Conference ('UNCTAD') Discussion Paper No. 195, 2009)

${ }^{112}$ HighQuest Partners, Private Financial Sector Investment in Farmland and Agricultural Infrastructure, (Organisation for Economic Cooperation and Development ('OECD') Food, Agriculture and Fisheries Papers, No. 33, 2010) 
an increase in prices, volatility and barriers to traditional farming models (e.g. moving from land-ownership to land-leasing) in these markets. ${ }^{113}$

In our view, the above evidence makes a strong case for investigating the role of financialisation in the food markets and, specifically, the extent to which price-cost squeezes are enabled by the presence of the same institutional investors in all, but the farming, segment of the value chain. Another important issue to note is that the majority, if not all, of the aforementioned processes can be considered as efficiency gains that have been enabled by the development of the market. However, this raises questions as to whether such efficiency gains, which have emerged at the expense of agriculture, are (i) sustainable, and (ii) normatively appropriate. We discuss our responses to these questions in the next section.

\section{Effects on Innovation}

Common ownership can affect the incentives of a firm to invest in innovation in two ways. Firstly, innovation that increases the profits of a firm by enabling them to reduce the price of a product and, thus, undercut their competitors, could result in an overall reduction of the sector's profits. Investments in R\&D may reduce the costs of the relevant firm. This reduction in costs may enable the firm to compete more effectively and increase its market share and this may eventually lead to it displacing and/or marginalising its competitors from the market, which is known the 'business stealing' or 'product market spillover' effect. ${ }^{114}$ This may have a negative impact on innovation, especially in light of common ownership as overlapping shareholders would likely consider increasing competition between firms they own highly undesirable.

Secondly, given the likely spillover effects, common ownership can affect the incentives of the relevant firm to invest in innovation. There may be a positive correlation between common ownership and innovation, provided the incentives for the commonly owned firms offset the disincentive of the spillover effect. For example, consider an independently-owned firm that incurs innovation-related costs. If intellectual property rights fail to provide a mechanism capable of appropriating the returns generated by the innovative efforts undertaken by a firm, ${ }^{115}$ competing firms may free-ride on the R\&D investments made by the initial firm. This free-riding creates a difference between the private and social marginal return of the new knowledge generated and is termed the 'spillover effect'. 116 Economic theory has submitted that if the other competing firms are independently owned,

\footnotetext{
${ }^{113}$ Isakson supra, at 106, 749-775.

${ }^{114}$ M. Anton, F. Ederer, M. Gine and M Schmalz, Innovation: The Bright Side of Common Ownership (2018), https://papers.ssrn.com/sol3/papers.cfm?abstract_id=3099578.

${ }^{115}$ See the seminal works of R. Nelson, The Simple Economics of Basic Scientific Research, 67 J. Politic. Econ. 297 (1959); F. Scherer, S. Herzstein Jr., A. Dreyfoos, W. Whitney, O. Bachmann, C. Pesek, C. Scott, T. Kelly and J. Galvin, Patents and the Corporation: A Report on Industrial Technology under Changing Public Policy, Report of Harvard University, Graduate School of Business Administration (1959); K. Arrow, Economic Welfare and the Allocation of Resources for Invention in The Rate and Direction of Inventive Activity (edited by R. Nelson, Princeton University Press, 1962).

${ }^{116}$ Economic studies have observed that gross social returns to R\&D may be, at least, twice as high as the private returns: N. Bloom, M. Schankerman and J. Van Reenen, Identifying Technology Spillovers and Product Market Rivalry, 81 Econometrica 1347 (2013).
} 
the spillover effect may serve to reduce the level of incentives for undertaking innovation. ${ }^{117}$ Conversely, if the competing firms are owned by separate groups of shareholders then the effect of technology spillovers in reducing the incentives for pursuing innovation will be particularly strong. Recent economic literature has contended that overlapping ownership in and/or of competing firms, for instance through common ownership by the same institutional investors, will enable the common shareholders to internalise, at least part of, these spillover effects, thereby reducing the impact of the free-rider problem on the incentives of a firm to innovate. Therefore, there would be scope to argue that this could lead to an increase in $R \& D$ spending and overall consumer and welfare surplus, provided the technology spillovers are sufficiently large. ${ }^{118}$ Nevertheless, these innovation-enhancing effects of common ownership are only likely to be found in markets that are not too concentrated. This chapter recommends undertaking a thorough investigation into the level of competition in industries with high concentration as the spillover thresholds below which common ownership may be welfaredecreasing is increasing with higher concentration levels (as measured by HHI). ${ }^{119}$ This is also the case with industries in which the spillover effect is low as a result of the relevant industry either not being R\&D intensive or of patent protection being weak. ${ }^{120}$

Thus, the overall effect of common ownership on innovation remains ambiguous and depends on which of the two aforementioned mechanisms applies. Studies have shown that firms with common ownership spend more on R\&D in markets with a spillover effect, however, this higher level of expenditure does not necessarily lead to higher innovation outputs, in particular the higher the business stealing effect is. ${ }^{121} \mathrm{We}$, as authors, submit that there is some correlation between the level of resources spent on R\&D and the level of innovative outputs developed by the firm. In view of the positive effects of common ownership in regard to the spillover effect, the higher the level of resources spent on $R \& D$ and the higher the level of innovative output generated, the more the firms are distant in the product market (and thus the business stealing effect is smaller). Therefore, in these specific circumstances, it is necessary to consider the positive effects of common ownership on innovation and whether they are capable of outweighing or mitigating the potentially anticompetitive effects of substantial technological spillovers. ${ }^{122}$

Hence, the overall effect needs to be considered on case-by-case basis; it is necessary to evaluate the positive and negative incentives to innovate that are present in the individual case. In the Dow/Dupont merger transaction (see Part IV.C), the Commission recently ruled

\footnotetext{
${ }^{117}$ This starting point does not take into account the possibility that firms may pursue strategies other than exclusion through the exercise of IP rights in order to appropriate returns from their innovation efforts. Compatibility and network effects may provide an important source of profits, particularly in the context of a financialised economy. For an overview, see, P. Hurmelinna-Laukkanen and K. Puumalainen, Nature and Dynamics of Appropriability: Strategies for Appropriating Returns on Innovation, 37(2) R\&D Manag., 95 (2007)

${ }^{118}$ See A. López and X. Vives, Overlapping Ownership, R\&D Spillovers and Antitrust Policy, J. Politic. Econ. (2018); He and Huang, (55), 2674-2718, which finds evidence that institutional cross-ownership facilitates product market collaboration (e.g. joint ventures, strategic alliances and/or within-industry acquisitions) and improves innovation productivity.

${ }^{119}$ López and Vives, supra, at 118.

${ }^{120} \mathrm{Id}$.

$121 \frac{\mathrm{Id}}{\mathrm{Id}}$

$122 \underline{\mathrm{Id}}$.
} 
that common ownership would, overall, have a negative effect on the incentives of firms that are commonly owned to compete and innovate.

\section{Summary of Theories of Harm}

The table below provides a summary of the different theories of harm/ adverse effects and their impact on competition.

\begin{tabular}{|c|c|c|c|}
\hline \multicolumn{3}{|c|}{ Type of Adverse Effect } & Mechanism \\
\hline \multirow[t]{3}{*}{ Horizontal } & $\begin{array}{l}\text { Uncoordinated } \\
\text { (Unilateral) }\end{array}$ & Management Incentives & $\begin{array}{l}\text { Shift in the conceptual framework from } \\
\text { seeking to maximise the profit of an } \\
\text { individual firm to maximising the value of the } \\
\text { investor's entire portfolio. } \\
\text { One mechanism concerning the changing } \\
\text { management incentives is that of voicing } \\
\text { shareholder preferences, which may involve } \\
\text { shareholders voting on proposals, or having a } \\
\text { say in relation to the nomination of managers } \\
\text { or in their remuneration, or in them receiving } \\
\text { informal communications that keeps them } \\
\text { informed of developments. Another possible } \\
\text { mechanism is shareholders reducing the level } \\
\text { of investment allocated to corporate } \\
\text { governance in order to force change. }\end{array}$ \\
\hline & Coordinated & Tacit Collusion & $\begin{array}{l}\text { Conceptual framework that defines } \\
\text { parameters under which the collusive } \\
\text { outcome is rendered more attractive in light } \\
\text { of the repeated interaction between firms. }\end{array}$ \\
\hline & Coordinated & Transparency & $\begin{array}{l}\text { Common ownership has the potential to lower } \\
\text { the level of information asymmetry between } \\
\text { firms and, thus, may facilitate the } \\
\text { coordination of activities or the maintenance } \\
\text { of collusive conduct between the relevant } \\
\text { firms. }\end{array}$ \\
\hline Vertical & \multicolumn{2}{|c|}{ Foreclosure in Vertical Market Structures } & $\begin{array}{l}\text { Commonly owned firms in vertically related } \\
\text { and/or adjacent markets are more likely to } \\
\text { trade with each other than with their } \\
\text { competitors. These vertical exclusionary } \\
\text { strategies have the potential to boost the }\end{array}$ \\
\hline
\end{tabular}




\begin{tabular}{|c|c|c|c|}
\hline & & & $\begin{array}{l}\text { profits of these firms whilst squeezing the } \\
\text { margins of their competitors. }\end{array}$ \\
\hline & $\begin{array}{l}\text { Exploitation } \\
\text { of vertical } \\
\text { market power }\end{array}$ & $\begin{array}{l}\text { Reduction in the capability } \\
\text { and incentives of the firm } \\
\text { to increase its productivity }\end{array}$ & $\begin{array}{l}\text { Commonly owned firms are able to more } \\
\text { effectively exploit the market power they } \\
\text { have in vertically related, although not } \\
\text { adjacent, markets vis-á-vis the most } \\
\text { competitive segments of the value chain. This } \\
\text { has the effect of reducing the percentage of } \\
\text { the surplus value captured by the competitive } \\
\text { segment and, thus, affects the capability and } \\
\text { incentives of firms operating in the } \\
\text { competitive segment to improve their } \\
\text { productivity. }\end{array}$ \\
\hline Innovation & $\begin{array}{l}\text { Restriction of } \\
\text { innovation } \\
\text { competition }\end{array}$ & $\begin{array}{l}\text { Reduction of the } \\
\text { incentives to compete, } \\
\text { which, in turn, reduces } \\
\text { innovation competition. } \\
\text { However, particularly in } \\
\text { the presence of strong } \\
\text { technological spillover } \\
\text { effects, common } \\
\text { ownership may have } \\
\text { positive effects on the } \\
\text { level of incentives a firm } \\
\text { has in relation to pursuing } \\
\text { innovation. }\end{array}$ & $\begin{array}{l}\text { Common ownership reduces the level of } \\
\text { competitive rivalry between the firms that are } \\
\text { commonly owned and, thus, reduces the level } \\
\text { of innovation competition between them. } \\
\text { However, common ownership may increase } \\
\text { innovation when the commonly owned firms } \\
\text { are present in an economic sector with } \\
\text { significant technological spillover effects; in } \\
\text { such sectors, common ownership may reduce } \\
\text { the risk of one firm's competitors free-riding } \\
\text { on its R\&D expenditure. }\end{array}$ \\
\hline
\end{tabular}

B. Beyond Traditional Competition (Price and Innovation) Effects: Effects on LongTerm Sustainability

The concerns raised by financialisation do not only exist in relation to common ownership, they exist in relation to the agricultural production more broadly as most FVCs, excluding the farming segment of such, have been subject to the process of financialisation in recent years. The major concentration of power that has occurred alongside different segments of the value chain has given rise to a fundamental issue that affects the entirety of the vertical dimension of this chain. The issue is that institutional investors, at every stage of the FVC, excluding the farming level, have mechanisms that allow them to extract margins at the expense of the farming segment. Whilst this arrangement can, on a case-by-case basis, be 
argued as being optimal and efficient, two issues emerge. The first one is whether such an arrangement poses a long-term threat to the farming industry. In response to this issue, we discuss the possibility of sharing the total surplus and using it to innovate, invest in sustainable practices and create buffers against economic shocks. The second issue is more normative and is centred on whether the system that creates the instruments and incentives that allow institutional investors to gradually gain market power and extract the greater share of profit margins is a fair and sustainable system from the perspective of social justice. We highlight that the issue of the same investors being present in most segments of the chain is under-researched, thus, the extent to which their presence contributes to adverse effects on the market is unclear.

The lack of a reliable profit stream can be a disincentive when it comes to undertaking long-term sustainable investment. Furthermore, it has been shown that institutional investors do not provide replacement incentives for sustainability through their economic decisionmaking. ${ }^{123}$ For example, the public consultation undertaken by the European Commission on how institutional investors factor environmental, social and governance ('ESG') information and/or the performance of companies or assets into their investment decisions showed that the majority of investors did not consider that their fiduciary duty regarding ESG was clear and binding enough, creating reasons to not consider it in investment decisions. ${ }^{124} \mathrm{~A}$ recent study of four food product supply chains (specifically tuna, shrimp, soy and beef), all of which were selected based on their economic importance on a global level and potentially adverse impact on the environment, found an abundance of links between the major financial institutions that hold shares in these chains. The study also showed that passive investors, as opposed to active investors, engage less with sustainability issues. ${ }^{125}$ Thus, part of investors' profits stemming from the value chain have likely been obtained at the expense of incentives and the profit margins required for long-term sustainable production being withdrawn.

Another sustainability issue relates to whether the farming industry does, in fact, receive a sufficient share of the total surplus so to render it robust when confronted by economic shocks. If farmers' profit margins are squeezed too much, this may prevent them from building a savings buffer capable of seeing them through a year of shocks, whether these be related to bad weather, trade wars etc. Existing instruments, such as impact investing, have been designed to incorporate sustainability issues as part of institutional investors' incentives (see a detailed discussion by Rogalska). ${ }^{126} \mathrm{We}$, the authors, believe that there is a real need for a policy-driven discussions related to the inclusion of such incentives being placed on a regulatory footing and on them being enforced by competition law.

Under current market conditions, firms and investors are able to efficiently and rationally follow their incentives and reap profits in ways that cater to their clients' interests.

\footnotetext{
${ }^{123}$ A. van Duijn, R. Beukers, R. Cowan, L. Judge, W. van der Pijl, L. Römgens and T. Steinweg, Financial Value-Chain Analysis (LEI Wageningen UR, Report No. 2016-028, 2016 ).

${ }^{124}$ Directorate General for Justice and Consumers, Summary of the Responses to the Public Consultation on Long-Term and Sustainable Investment, European Commission Document, JUST/A3 (2016).

${ }^{125}$ Apart from the retail banks, which often have developed sustainability policies. However, the authors note that this financing is largely based on syndicated loans and, thus, this changes the dynamics of the leverage of these banks.

${ }^{126}$ M. Rogalska, Globalisation and Financialisation of the Economy Impact Investing at Scale as a Promising Response, Weatherhead Centre for International Affairs, Harvard University (2016).
} 
Further evaluation is needed to understand whether this is a sustainable way forward or whether cost-cutting and other activities, which have been enabled by a concentration in market power, have reduced the incentives for, and profit surplus available to, farmers to innovate, invest into sustainable practices and withstand economic shocks. Related to this are two normative issues. The first relates to determining whether it is appropriate that the majority of the total surplus is extracted by the institutional investors. The second involves examining the likely an long-term effects of institutional investors extracting such. Finally, there is need for further research into the existence and nature of the additional incentives that exist for investors who hold shares in several segments of the market.

\section{Evaluation of the Effects of Financialisation on the Food Value Chain: Evidence and Controversy}

The effects of financialisation on the majority of segments comprising the value chain has been linked to a range of observable market trends that have been viewed as having the potential to adversely affect the economy in the long-term. The controversial nature of these effects and the fact that they are being driven by firms seeking to pursue the interests of their shareholders in the most optimal way merits a separate discussion, a discussion we do develop in the following section. Once again, we stress that whilst it is not unlikely to expect the same incentive mechanisms pertaining to common ownership in horizontal markets to play a role in vertical markets, more research is needed.

Burch and Lawrence analyse how private equity takeovers of supermarkets have transformed the food retail sector. ${ }^{127}$ They conduct a case-study, one which centres on a private equity consortium's takeover of Somerfield Supermarkets (UK). From this, they identify four strategies that are employed by financial actors as a means of generating shareholder value. The first strategy involves narrowing the retailer's product line and reducing the number of suppliers, thereby streamlining the sourcing process (which may include closing some distribution centres) and reducing costs. The second consists of reducing the overall number of employees (many of whom previously worked in said distribution centres) whilst increasing the workload (i.e. the rate of exploitation) of the remaining workers. The third involves disregarding previous commitments to environmental quality and the well-being of food producers in the global South, as illustrated by Somerfield's withdrawal from the Ethical Trading Initiative ('ETI'), an initiative which sets labour standards for developing country suppliers. The final strategy consists of de-bundling and repackaging assets. In the case of Somerfield this included the introduction of an operating company/property company (opco/propco) arrangement -Somerfield sold its real estate properties to a newly created subsidiary of itself, which, in turn, leased the property back to Somerfield. It is contended that these transformations do worsen the economic situation of specific groups in the market (specifically of farmers and labour force) and they create long-term threats to the country's economy and environmental sustainability. However, at the same time, these transformations can be considered to be steps that improve

\footnotetext{
${ }^{127}$ See B. Burch and G. Lawrence, Towards a Third Food Regime: Behind the Transformation, 26(4) Agr. Hum. Values 267-279 (2009); B. Burch and G. Lawrence, Financialization in Agri-Food Supply Chains: Private Equity and the Transformation of the Retail Sector, 30(2) Agr. Hum. Value, 247-258 (2013).
} 
the efficiency of the relevant company in the current globalised market as they focus on reducing its costs and maximising its returns for its shareholders.

Numerous techniques can measure the aforementioned effects, however, a more complex issue is that of creating a framework capable of evaluating and comparing these longer-term effects against the shorter-term increases in investors' profits that firms achieve through these activities. Studies have employed scanner and retail data to measure prices at different stages of the value chain. ${ }^{128}$ A similar approach has been taken in relation to measuring changes in the labour market, changes which can be attributed to the increased level of common ownership. However, a greater challenge is evaluating these effects against the value generated by institutional investors for their clients, with such persons potentially including large parts of the society (e.g. persons relying on pension funds). Thus, we believe that there needs to be a coherent evaluative framework that enables one to quantify and compare the long-term effects of such on the economy against the shorter-term benefits received by shareholders and make meaningful recommendations for regulative purposes, including competition law enforcement.

Another important long-term effect of financialisation is the withdrawal of valuable sectors from the (domestic) economy. For example, Ashman, Mohamed and Newman explore the development of Anglo American PLC (henceforth, "Anglo"), by far the most important South African mining companies. ${ }^{129}$ In the 1990s, Anglo had 100 subsidiaries in South Africa. Its manufacturing accounted for about $30 \%$ of its revenues and its activities collectively accounted for over $40 \%$ of the Johannesburg Stock Exchange market capitalisation. By 2007, however, due to its restructuring, Anglo had either moved or sold a large number of its segments, segments which had been considered to be very important for the South African economy. Specifically, it shifted the engineering and design segments of Boart Longyear, a company which produced tools and equipment and services for the international mining industry, offshore. As a result of the technologically advanced position that South Africa had built due to its innovation in mining and the processing of minerals, this was considered to be an important area of capital and transport equipment. Similarly, in 2012, Anglo had shifted the more value-generating and more technologically advanced parts of its paper and packaging business to Europe. The consequence of this was that the operations/ segments left in South Africa were those that generated lower value and, thus, there exports were reduced. The shift rendered the country more reliant on importing more expensive manufactured products, products which have previously been produced in the country. As noted earlier, these actions bring clear benefits to shareholders in the market. They also can be considered as actions that have been pursued in the interest of investors. However, these actions do pose a longer-term threat to the overall competitiveness of the economy. Although such effects are difficult to quantify, it is necessary to do so in order to evaluate the benefits of these actions against the threats they pose to a country's economy.

\footnotetext{
${ }^{128}$ See S. Villas-Boas, Vertical Relationships between Manufacturers and Retailers: Inference with Limited Data, 74(2) The Rev. Econ. Stud. 625-652 (2007); S. Villas-Boas, Using Retail Data for Upstream Merger Analysis, 3(4) J. Compet. Law Econ. 689-715 (2007).

${ }^{129}$ S. Ashman, S. Mohamed and S. Newman, Financialisation of the South African Economy: Impact on the Economic Growth Path and Employment (Discussion Paper of the United Nations Department of Economic and Social Affairs 2013).
} 
A more short-term piece of evidence that may prove helpful in mapping the negative effects of financialisation on the market is the mismatch between industry performance and shareholder returns. Ashman, Mohamed and Newman refer to a recent study by PWC, which highlights that trends relating to the share prices of mining companies are not reflected in changes to commodities prices. ${ }^{130}$ PWC reports that "2011 was a year of a growing disconnect for the mining industry. Mining company stocks significantly underperformed the broader markets and lost value despite record profits, and the disconnect between share values and many commodity prices widened". The PWC report shows that the global mining industry is facing even more problems, lower profits and lower share prices. Such disconnect may be more readily observable in the FVC. For example, if shocks on the production side (e.g. a reduction in crops) are happening at the same time as shareholders are receiving high returns, regulators may need to consider and respond to concerns about how these shocks are absorbed into and by the value chain.

This brings us to the more general questions concerning the functioning of markets in the modern world. The way we currently think about corporate governance does not fully account for the fact that most investors have diversified portfolios. This has already been recognised as an issue in mergers and acquisitions. For example, in the context of common ownership, a company may not be incentivised to bargain over the split of the merger premium. A diversified investor, who holds a proportional amount of both companies' shares, does not care about the most competitive split since it does not necessarily maximise the overall value of their holding. For example, if both companies act in the best interest of said investor, they would minimise the legal and negotiating costs, avoid pushing one of the companies to raise debt to pay more and not run the risk of one of the companies exiting the deal due to disagreement about the split of the benefits; they would do this because all of these actions reduce the benefits the diversified shareholder would receive, compared to the benefits of a non-competitive merger. Additionally, the current management of the companies has been academically and professionally trained to think in the context of the modern portfolio theory. From this perspective, both economic and legal researchers need to incorporate this understanding into the way the market and its incentives are analysed and regulated.

The potential issues that institutional investors create for the less concentrated segments of the value chain, such as farmers, also raises questions. Diversified institutional investing offers many advantages and much of society relies on such. For example, pension funds are able to hedge risks, benefit from low-cost capital management and guarantee longterm returns to their clients. Yet, at the same time, there is evidence that anti-competitive incentives may exist in this system. This raises a number of important research directions. One involves determining the methods and evidence needed to conclude whether such do, in fact, exist. Another consists of considering the possible changes that can and should be made whilst ensuring that the positives institutional investment brings are retained. To enable policy interventions, we need to do multiple things. First, establish whether the potential costs to the economy outweigh the well-established benefits of diversification. Second, outline a

${ }^{130}$ Price Waterhouse Coopers ('PWC'), Mine: The Growing Disconnect (Report 1 2012). 
method for quantifying the costs of possibly lowering competition and squeezing the margins of more vulnerable players in the value chain, such as farmers. Third, make a value judgement as to how to fairly allocate the surplus in the market and determine whether it should be extracted by the party that is better placed to extract it or shared more equally. Fourth, undertake further research into the way that the uncoordinated effects of common ownership may be affecting the incentives of institutional investors present in several segments of the value chain. In particular, promoting the interests of same shareholders in more than a single segment of a value chain may lead to margins being squeezed to a greater degree as firms may lack the motivation to undercut each other not only horizontally but also vertically. Furthermore, the incentive to maximise the common owners' profit margins may lead to individual sectors neglecting the 'optimal' activity within that sector.

It is important to note that, despite the argument about common ownership creating wrong incentives, within the current set-up firms and shareholders are responding correctly to the current market incentives. Managers, presumably, are not acting against the interests of their shareholders while the latter group are focused on the long-term returns they receive. Managers are conducting themselves in the way that the believe will maximise the value of their shareholders' portfolios. Equally, shareholders are investing rationally; they are investing in diversified portfolios that maximise risk-adjusted return. Yet the functioning of this system in its current state creates a negative externality for the wider economy. In our view, this tension indicates the need for further thorough investigation into the nature of the incentives that the current economic and legal framework creates, the possible outcomes of these incentives and the ways in which to alter the framework in order to achieve the desired improvements.

\section{The Prevalence of Common Ownership in the Global Food Value Chain: Empirical} Evidence and Possible Effects

Some of the competition authorities that have examined the recent seed mergers have raised concerns over common ownership by the same financial investors in the various segments of the FVC, and, more specifically, in seeds and crop protection chemicals. In particular, the European Commission noted in its recent Dow/Dupont merger decision that there was a significant level of common shareholdings across BASF, Bayer, Dow, DuPont, Monsanto and Syngenta (i.e. the 'Big Six'). The shareholding of these firms has been characterised by a tail of atomistic shareholders, with most of the listed shareholders having a less than $0.01 \%$ equity share. ${ }^{131}$ Such a tail of atomistic equity holders may be less likely to be able to exert influence over general assemblies and the companies' management. Thus, the Commission concluded that "the control exerted by large shareholders seems to be more important than their ownership equity share suggests". ${ }^{132}$ Furthermore, according to Annex 5 included in the Dow/Dupont EU Commission decision, "Dow, DuPont and Monsanto seem to be the most 'consanguine' agrochemical firms, as they share a significant number of equity holders with, overall, large positions on all of these three firms". ${ }^{133}$ Indeed, a small number of

\footnotetext{
${ }^{131}$ See Commission Decision, Case M.7932 - Dow/DuPont (2017), 2339-2340 and 2347.

${ }^{132}$ Id. Annex 5, 32-33.

133 Id. Annex 5, 13.
} 
common shareholders, collectively own around $21 \%$ of BASF, Bayer and Syngenta and around $29 \%-36 \%$ of Dow, DuPont and Monsanto. ${ }^{134}$

The Commission went even further and explored the shareholding structure outside the Big Six. It found that a significant number of shareholders in the Big Six also held shares in FMC, a competitor that is no longer present in active R\&D discovery. Thus, the Commission took the view that the conclusions reached for the integrated R\&D players and Monsanto in relation to their concentrated shareholdings and their common shareholdings also extend to some of the non-vertically integrated shareholdings. ${ }^{135}$

We confirmed these findings by conducting our own research into the shareholding of these companies by institutional investors. We selected 33 publicly traded companies on the NYSE, NASDAQ and LSE across various parts of the FVC. The FVC is represented by companies operating in sectors, such as:

- Biotechnology:

○ Illumina ('ILMN') and Genus ('GNS.L').

- agriculture seeds and crop protection producers:

- Monsanto ('MON'); E.I. Du Pont Nemours and Company ('DD'); the Dow Chemical Company ('DOW'); Agrium ('AGU') and American Vanguard Corporation ('AVG').

- fertiliser producers:

- Potash Corporation of Saskatchevan Inc. ('POT'); the Mosaic Company ('MOS') and CF Industries Holdings ('CF').

- farm and construction machinery manufacturers:

- Deer and Company ('DE'); AGCO Corporation ('AGCO') and $\mathrm{CNH}$ Industrial ('CNHI').

- food producers, including major branded food diversified manufacturers:

- Archer Daniels Midland Company ('ADM'); Bunge Limited ('BG'); Tyson Foods ('TSN'); the Kraft Heinz Company ('KHS'); Conagra Brands ('CAG'); Pinnacle Foods ('PF') and Post Holdings.

- animal health medicines, vaccines and animal safety products:

○ Zoetis ('ZTS') and Neogen Corporation ('NEOG').

- pet products:

○ Blue Buffalo Pet Products ('BUFF').

- some others.

Our analysis covered the full value chain, all the way from leading biotechnology companies producing genome sequencing equipment to seeds and animal breeding companies, from fertiliser and pesticides manufacturers to farm equipment, and from farmers and raw food manufacturers to major food diversified holdings.

The information about investors was taken from Bloomberg (date of analysis June 1213, 2017). Overall, we analysed the investor profile of 33 public companies and 2,569 investors into these companies. Overall, these investors account for 10,239 links

\footnotetext{
${ }^{134}$ Id. Annex 5, 80.

135 Id. Annex 5, 18.
} 
(relationships) across 33 publicly traded agriculture and food companies. The results of our research are shown in the following figures and tables.

Figure 2: Helicopter View of Investors in the Publicly Traded Companies Dominating the FVC

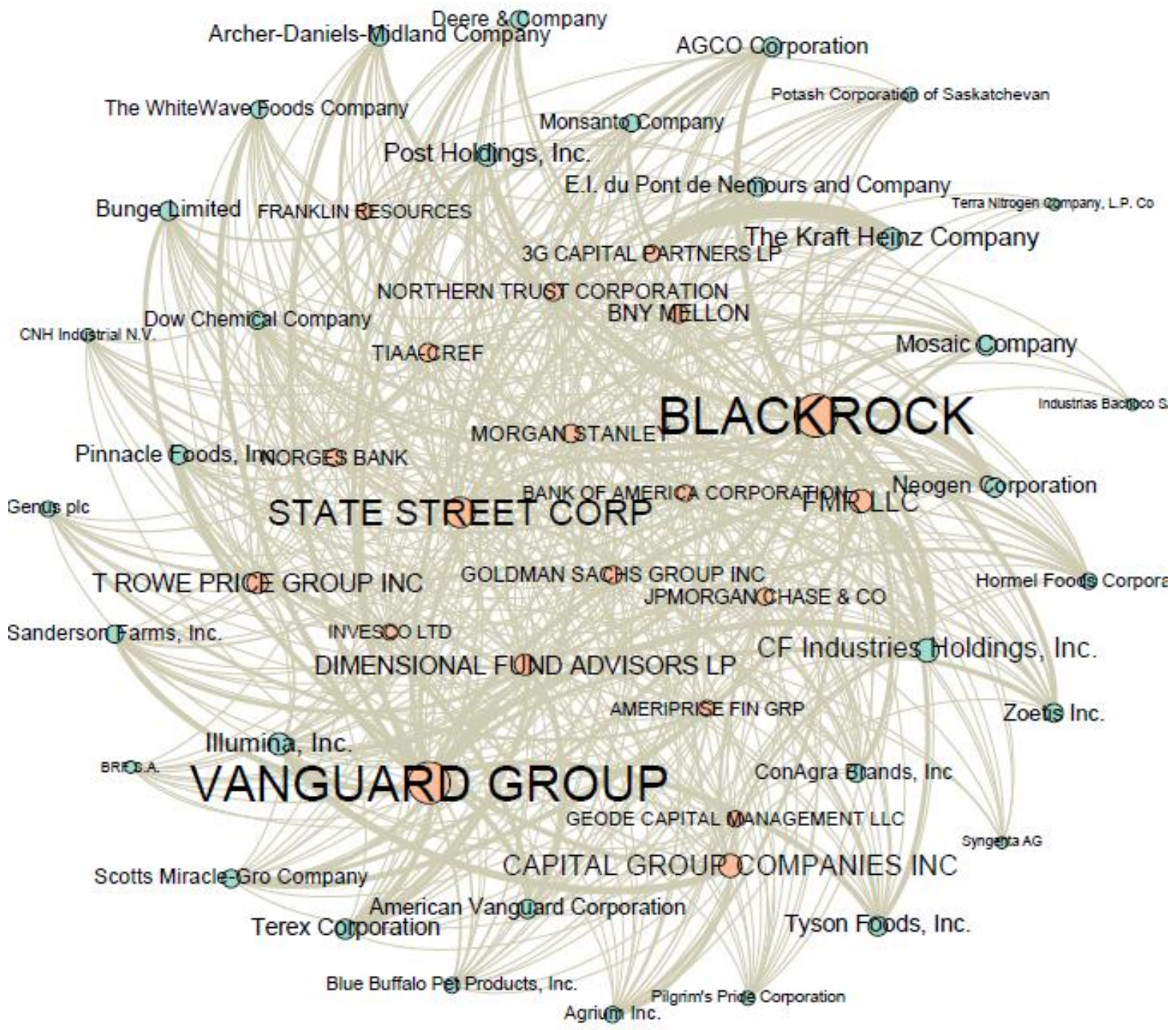

Top-20 investors in the 33 publicly owned food \& agri companies. Source: Authors' Calculations ${ }^{136}$

The helicopter view shows a clear group of twenty top investors. Using a page-rank algorithm, ${ }^{137}$ we identified key investors - the importance/influence of an investor is

\footnotetext{
${ }^{136}$ We included 33 public companies (blue colour) and 2,569 investors (orange colour) with 10,239 links. The names of the 20 major investors that represent an influential cluster are provided.

${ }^{137}$ S. Brin and L. Page, The Anatomy of a Large-Scale Hypertextual Web Search Engine, in Proceedings of the Seventh International Conference on the World Wide Web, 107-117 (1998).
} 
indicated by the size of the node and the thickness of relationship between the investor and the investee represents the percentage of shares owned.

The most active investors include:

- Leading global investment \& wealth management corporations:

○ Morgan Stanley, Goldman Sachs, UBS, Deutsche Bank, etc.

- Banks:

- BNY Mellon, Bank of New York, Bank of America Corporation, etc.

- Asset-managers and financial services providers:

- BlackRock, Vanguard Group, State Street, TIAA, Wells Fargo, etc.

- Pension and sovereign wealth funds;

- Central banks:

○ Norges Bank, the central bank of Norway.

- Investment funds:

- Dimensional Fund Advisors, Geode Capital Management etc.

- and other players.

Figure 3: The Core Investors (top-5) in Seeds and Traits 


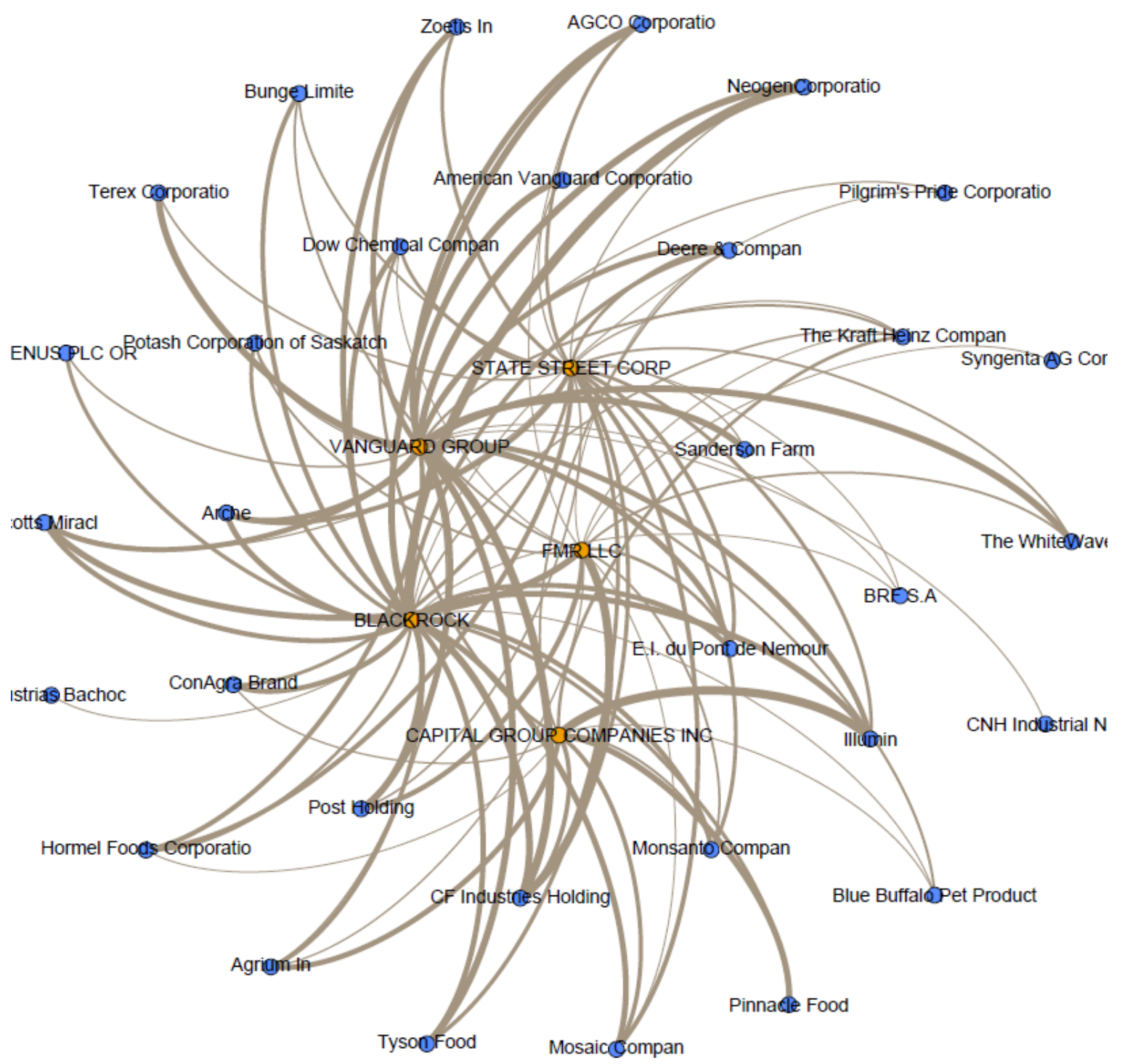

Source: Authors' Calculations

The top twenty investors from the list of 33 have been ranked by their activity (i.e. the number of companies into which they have invested and the maximum possible ties) and are presented in the table below.

Table 1: Top 20 Investors

Investor

Morgan Stanley

BlackRock

\section{Number of investees}

$\%$ of total investees covered

30

29
$91 \%$

$88 \%$ 
Dimensional Fund Advisors LP 29

$88 \%$

Goldman Sachs

29

$88 \%$

State Of California

29

$88 \%$

Norges Bank

28

$85 \%$

Northern Trust

28

$85 \%$

State Street Corporation

27

$82 \%$

TIAA

27

$82 \%$

Bank of America

25

$76 \%$

Deutsche Bank AG

25

$76 \%$

Geode Capital Management LLC

25

$76 \%$

UBS

25

$76 \%$

Charles Schwab Corporation

24

$73 \%$

The Vanguard Group

24

$73 \%$

Ameriprise

22

$67 \%$

Invesco

22

$67 \%$

Wells Fargo

22

$67 \%$

FMR LLC

21

$64 \%$

Source: Authors' Calculations

Note that each investment company or mutual fund holds several funds, each of which could be managed in a "passive" or "active" way. More details on share ownership pertaining to the most active investors into the global FVC is presented in Annex 1. 


\section{Is Competition Law Ready for Financialisation?}

At the present moment, competition law has largely ignored the process of financialisation. Its narrow consideration of the effects of market power on a product market is the source of the problem. The literature on common ownership constitutes a first attempt to move away from this product market focus and consider the full extent of "real competition", which takes place in various dimensions and, as one would expect in the era of financial capitalism, is gaining competitive advantage in financial and future markets, both of which constitute an important dimension of the modern competitive game. However, this move away does not mean that competition law sufficiently engages with the process of financialisation; only if common ownership has a price or non-price effect on a specific product market does competition law intervene. Cross-shareholding and common ownership are often raised as concerns. The reason is that the current indicators of concentration, which are based on the concept of 'control', are not broad enough to encompass the potential restriction of competition that may occur through passive investors controlling minority shareholdings in various companies in the relevant market segment. Thus, questions have been raised as to the appropriate scope of merger control and the degree of scrutiny of common ownership undertaken by common ownership. Thus, in relation to exploring the type of competition assessment that would be suitable when confronted with the various price and non-price effects of common ownership, the recent agro-chem mergers provide some interesting insights.

\section{A. Financialisation and the Scope of EU Competition Law}

EU competition law applies to 'undertakings', not to 'investors'. Article 101 TFEU applies to agreements between undertakings, decisions by associations of undertakings or concerted practices between undertakings. Article 102 TFEU applies to the abuse of a dominant position by an undertaking. Council Regulation (EC) No 139/2004 on the Control of Concentrations Between Undertakings (henceforth, the "EU Merger Regulation" or "EUMR") also applies to a concentration between undertakings or part of undertakings. The concept of 'undertaking' is functional and is interpreted as covering any entity engaged in economic activity. Competition law does not delve further into the concept of 'undertaking'; for the purposes of establishing liability, an undertaking remains the sole unit of interest for competition law. Inside the 'black box' of an undertaking, one may of course find a variety of diverse interests that explain the competitive strategies and conduct of these economic entities, which could be of interest for competition law. We put aside the situation in which an undertaking may be a physical person exercising an economic activity, to only focus on that of a firm, or in legalese, an entity holding a legal personality. Depending on the chosen theory of the firm, this may be perceived as a set of contracts between various business participants that interact within a certain economic and legal context, ${ }^{138}$ or as "a nexus of

\footnotetext{
${ }^{138}$ See, for instance, E. Fama, Agency Problems and the Theory of the Firm, 88(2) J. Politic. Econ. 288 (1980), which views firms as a "set of contracts among factors of production, with each factor motivated by its [own] self-interest"; M. Jensen and W. Meckling, Theory of the Firm: Managerial Behaviour, Agency Costs and
} 
agency relationships, including managerial lines of authority, employment and structures of governance". 139

This may have implications as to the assumption of the 'shareholder primacy' principle in the theory of the firm as a nexus of contracts, the primary duty of the management and the officers of the corporation being to maximise value for the shareholders. If the firm is perceived as the principal, other objectives, such as the long-term viability of the corporation, its reputation and broader social objectives other than just profits, may be followed by the specific entity. This approach may also change who are the business participants that matter most. In the traditional theory of firms as a set of contracts, these are the equity investors/shareholders and managers. Approaches other than the 'nexus of contracts' one, emphasise the role played by non-owner managers and employees, as well as other capital providers. These can be creditors or participants employing mixed debt-equity instruments, such as hybrid securities (e.g. convertible loans, preference shares, derivatives and other innovative financial instruments), which are along the "debt to equity continuum". ${ }^{140}$ The concept of 'control' plays an important role in defining the level of intervention by competition law against an economic entity. This concept determines the tangible/intangible assets that constitute the core of the undertaking and defines its boundaries, thereby enabling the relevant competition authority to determine the persons/agents operating within it. If they have pursued anti-competitive strategies, these persons may engage the undertaking's liability.

The concept of 'control' also plays an important role in merger control. In the EU, only those transactions that result in a lasting change in the structure of the market fall within the scope of the substantive law provision of the EUMR. This prohibits a concentration in case it produces a significant impediment of effective competition and satisfies the conditions of Article 3 of the EUMR. ${ }^{141}$ There are two primary types of concentrations: i) those that arise from a proper merger and acquisitions ('M\&A') transaction between previously independent firms, ${ }^{142}$ and ii) those that arise from the acquisition of control. ${ }^{143}$ In relation to the former type of concentration, this can arise in one of two ways. The first way involves two or more firms merging and, thereby, ceasing to exist as separate legal entities. The second way consists of the target firm being absorbed into the firm seeking to acquire it; this results in the target firm ceasing to exist as a legal entity whilst the acquiring firm retains its legal identity. ${ }^{144}$ In the latter type of concentration, whilst the target firm does not cease to

Ownership Structure, J. Financ. Econ. 310 (1976), which states that "it is important to recognise that most organisations are simply legal fictions which serve as a nexus for a set of contracting relationships among individuals... including firms"; F. Easterbrook and D. Fischel, The Economic Structure of Corporate Law (Harvard University Press, 1996).

${ }^{139}$ E. Orts, Business Persons - A Legal Theory of the Firm, 60 (Oxford University Press, 2013) .

140 The terminology 'debt to equity continuum' was coined in the publication by Moody's, "Tool Kit for Assessing Hybrid Securities" (1999).

${ }^{141}$ See Recital 20 of Council Regulation (EU) No. 139/2004 of 20 January 2004 on the Control of Concentrations Between Undertakings (the EU Merger Regulation) ('EUMR') Official Journal L 24, 29.01.2004, 1-22.

${ }^{142}$ Id. Article 3(1)(a).

${ }_{143}$ Id. Article 3(1)(b).

144 Commission Consolidated Jurisdictional Notice under Council Regulation (EC) No. 139/2004 on the Control of Concentrations Between Undertakings, [9]. 
exist as a separate legal entity, its control is transferred, in a lasting way, to another firm or to multiple firms for it to be exercised jointly. ${ }^{145}$

According to Article 3(2) of the EUMR, 'control' means being able to exercise decisive influence on a firm, most commonly, by virtue of a controlling shareholding, which can be lower than $50 \%$ where the rest of the shareholders are dispersed. ${ }^{146}$ Control can, therefore, be exercised on a de jure basis by virtue of a majority of voting rights, or on a de facto basis where the remaining shareholdings are fragmented resulting in smaller shareholders being unable to veto the relatively larger shareholder. ${ }^{147}$ Hence, the concept of control does not cover only cases in which the acquiring undertaking controls a majority of voting rights (and so has the power to take strategic decisions) but also cases in which the undertaking has the power to veto strategic decisions (i.e. 'negative sole control'). ${ }^{148}$ Control can also be acquired on a contractual basis, provided the contract is to last for a long period of time and transfers control over management and resources even if it does not do the same in relation to property rights or shareholdings. ${ }^{149} \mathrm{~A}$ 'transfer of control' can be in relation to a mere part, rather than the whole, of a firm, as long as it confers a significant enough level of turnover that the firm has some level of market presence. ${ }^{150}$

This does not necessarily mean that the Commission does not occasionally pierce the corporate veil in order to assess the real influence of the various shareholders. In Anglo American Corporation/Lonrho, ${ }^{151}$ the former company, Anglo American Corporation (henceforth, "AAC"), a diversified South African company involved in mining, finance, commerce and industry, acquired $24.13 \%$ of Lonrho, a UK company active in mining, agriculture, trading and property. The Commission amalgamated the shareholding that AAC would acquire in Lonrho with that of two other shareholders on account of the fact that the latter would vote in accordance with the instructions given to them by AAC. In this light, it examined whether AAC would, whether solely or jointly with these two shareholders, de facto acquire the possibility of exercising decisive influence over Lonrho and, therefore, controlling it. The Commission concluded that AAC would acquire sole control of Lonrho. In coming to this conclusion, it took into account the following considerations: i) a $27.47 \%$ shareholding would have amounted to a majority of the votes cast at past meetings, ii) the next largest shareholder owned 3\% of the shares in Lonrho and simultaneously held shares in $\mathrm{AAC}$ itself, iii) AAC was the only industrial/mining company with a significant shareholding in Lonrho, which prompted concerns that AAC could utilise its position to increase its influence over the board, and iv) Lonrho's directors, who held a total of $0.12 \%$ of the shares in the company, would not be expected to vote against AAC in its capacity as the main shareholder.

In a similar vein, the provisions of EU competition law, contained in the TFEU, are enforced against the undertaking the conduct of which constitutes a restriction or breach of

\footnotetext{
${ }^{145} \underline{\mathrm{Id}} .11$.

${ }_{146}$ See, for example, Arjomari-Prioux-SA/Wiggins Teape Appleton plc (Case IV M.025) C(1990) 321, [4].

${ }^{147} \mathrm{Ib}$ Id.

${ }^{148}$ Jurisdictional Notice, supra at 143, 54 .

149 Jurisdictional Notice, supra at 143,18 .

${ }^{150}$ Id. 24.

${ }^{151}$ Case COMP/M.754 Anglo American Corporation/Lonrho, [1998] OJ L 149/21, [31]-[39].
} 
competition law and, if the principle of parental liability is applicable (i.e. the relevant undertaking is a wholly-owned subsidiary, the conduct of which is determined/controlled by its parent company), against the parent company. ${ }^{152}$ Provided the parent company exercises decisive influence over the subsidiary and owns all of its shares, it will be held strictly liable for the actions/material omissions taken by its subsidiary that breach competition law. ${ }^{153}$ This presumption, the 'AKZO-Nobel presumption', may be rebutted in very specific circumstances, including situations in which the parent company is an investment company and behaves like a purely financial investor. However, as espoused by the General Court in Garantovaná v Commission, this exemption is narrowly defined and only covers cases in which "an investor holds shares in a company in order to make a profit, but refrains from any involvement in its management and in its control". ${ }^{154}$ In Versalis $v$ Commission, the CJEU held that "in the specific case where a person holds all or almost all of the capital of an interposed company which, in turn, holds all or almost all of the capital of a subsidiary of its group which has committed an infringement of EU competition law, there is also a rebuttable presumption that that holding company exercises a decisive influence over the conduct of the interposed company and indirectly, via the company, also over the conduct of that subsidiary". 155

Even if the jurisprudence of the EU Courts seems to pierce the corporate veil and the enterprise liability doctrine, which is exemplified by its development of the AKZO-Nobel presumption, the jurisprudence clearly excludes other business participants, such as creditors (debt-holders) and equity-holders, who are not involved in the management of the company but simply hold shares "in order to make a profit" from the scope of liability under competition law. Nevertheless, private equity investors and hedge funds may not be caught by this exemption from the AKZO-Nobel presumption as they are usually involved in the supervision of the companies in their portfolio, at least from a corporate law perspective. In Gigaset $v$ Commission, the General Court confirmed a Commission decision that held Arques (now Gigaset), a German private equity fund that specialised in directly acquiring and restructuring companies in distress, jointly liable for a fine imposed on SKW StahlMetallurgie, a company that had participated in a cartel involving calcium carbide and magnesium based reagents for the steel and gas industries. ${ }^{156}$ More recently, the Commission found the private equity arm of Goldman Sachs liable for the anti-competitive conduct of

\footnotetext{
${ }^{152}$ This is often referred to as the 'AKZO Nobel presumption': see Case C-97/08 P, Akzo Nobel and Others $v$ Commission [2009] ECR I-8237.

${ }^{153}$ In the absence of evidence to the contrary, the legal presumption meant that the Commission (or the claimant) could solely rely on the $100 \%$ shareholding of the subsidiary by its parent company; there is no need to prove that the parent company had in fact exerted a decisive influence.

${ }_{154}^{15}$ Case T-392/09 1, Garantovaná a.s. v Commission ECLI:EU:T:2012:674, [52].

155 Joined Cases C-93/13 P and C-123/13 P European Commission $v$ Versalis SpA \& Eni SpA ECLI:EU:C:2015:150, [43]. In this case, Eni was found to be, either directly or indirectly, holding between 99.93\%-100\% of the capital of the companies within the group. Consequently, the presumption of parental liability was considered applicable.

${ }^{156}$ Case T-395/09 Gigaset AG v Commission ECLI:EU:T:2014:23. For a similar fact pattern, see Case T-392/09 1, Garantovaná, (153), which involved a private equity firm controlling a majority stake in a company that had participated in the calcium carbide cartel.
} 
Prysmian, one of its former portfolio companies, which had participated in the power cables cartel. $^{157}$

Thus, a distinction can be seen between situations of 'managerial operational control', which give rise to the AKZO-Nobel presumption, and 'financial structural control' by passive investors (i.e. debt or equity holders), which may serve to rebut the presumption. ${ }^{158}$ This creates a void in merger control, which is non-sensical in the era of financialisation. The financialisation of the modern corporation has led to the principle of shareholder value becoming dominant. It has also led to there being a greater focus on short-term share prices, an increase in the level of leveraging through debt, the development of hybrid financial instruments and an increase in the importance of the role played by institutional investors, particularly financial institutions and sovereign wealth funds. However, the situation has become even more complex. For example, financial leveraging facilitates equity buy-backs and in doing so raises stock prices, which in turn, affect the level of revenue collected by the company's management via stock options pay. Stock options pay affects the incentives of managers, aligning their interests with those of the financial investors, including the most important creditors of their company, who, with equity owners, jointly control its financial structure. However, despite these developments, EU competition law still focuses on managerial operational control and, seemingly, ignores financial structural control or influence.

The definition of 'control' has a wider scope in the UK. Under the Enterprise Act 2002, minority shareholdings will be subject to the rules regarding merger control where there is a possibility that "material influence" may be exercised over the acquired business. The Merger Assessment Guidelines, ${ }^{159}$ proffered by the UK Competition Commission and Office of Fair Trading, provide guidance on assessing the concept of 'material influence'; it focuses mainly on the importance of voting rights and board representation. Factors that may be relevant to the assessment of a particular shareholding include the distribution and holders of the remaining shares, in particular whether the acquiring entity's shareholding makes it the largest shareholder, patterns of attendance and voting at recent shareholders' meetings based on recent shareholder returns, the existence of any special voting or veto rights attached to the shareholding under consideration and the status and expertise of the acquirer and its corresponding influence with other shareholders. ${ }^{160}$

$B S k y B / I T V$ is one of the leading cases on the issue of material influence. The Office of Fair Trading ('OFT'), which was the predecessor of the Competition and Markets Authority ('CMA'), considered the issue of material influence. The issue arose in relation to the acquisition by BSkyB, by far the UK leading pay-TV operator, of a $17.9 \%$ stake in ITV, the leading commercial free-to-air TV operator. The OFT concluded that the acquisition of this minority stake would give BSkyB material influence. It found that, on the basis of evidence of attendance and voting at recent ITV shareholders' meetings, BSkyB's proposed shareholding would, in practice, likely allow it to block special resolutions at ITV

\footnotetext{
${ }^{157}$ Commission Decision, Case COMP ANT.39.610 Power Cables (2014).

158 On this distinction, see Orts supra at 139, 86 and 88.

${ }^{159}$ Competition Commission and Office of Fair Trading, Merger Assessment Guidelines, OFT1254 3.2.8-3.2.10 (2010).

${ }^{160}$ Id. 3.2.10.
} 
shareholders' meetings. The OFT found that turnout at ITV shareholders' meetings had ranged between $63 \%-70 \%$. Therefore, BSkyB's proposed $17.9 \%$ stake would have enabled it to exercise more than $25 \%$ of the votes cast at these meetings. The OFT also made the following observations. Firstly, BSkyB could obtain board representation as a result of its shareholding. Secondly, BSkyB was the only significant trade shareholder and had substantial industry expertise. Thirdly, BSkyB was the largest individual shareholder and ITV's corporate governance policy was to hold frequent discussions with its major shareholders. Lastly, the remaining shareholdings in ITV were fragmented and a number of other ITV shareholders had cross-shareholdings in both of the merging firms. This approach was upheld by the Competition Appeal Tribunal in 2008, ${ }^{161}$ and by the Court of Appeal in 2010. ${ }^{162}$

In Ryanair/Aer Lingus, ${ }^{163}$ the UK Competition Commission, which has since been replaced by its successor, the CMA, focused its analysis on the obstacles which a shareholder can impose in order to prevent a company from freely pursuing its own commercial objectives. The Competition Commission concluded that by limiting Aer Lingus's ability to pursue its own independent commercial policy and strategy, Ryanair's minority shareholding would have led to a reduction in Aer Lingus's effectiveness as a competitor. ${ }^{164}$

In the United States, Section 7 of the Clayton Antitrust Act of 1914 (as amended by the Celler-Kefauver Anti-Merger Act of 1950 and then again in 1980), was adopted against a backdrop of increasing concern about the concentration of US businesses. It prohibits not only acquisitions of the stock by one corporation of another but also acquisitions of assets where the "effect of such acquisition may be to substantially lessen competition, or to tend to create a monopoly". ${ }^{165}$ This provision captures acquisitions by persons other than corporations, specifically natural persons, partnerships, other unincorporated associations and business entities. It should be noted that there is no express shareholder percentage ownership trigger or 'material influence' test, rather it is the value of the acquisition which may trigger a filing under the Hart-Scott-Rodino ('HSR') Antitrust Improvements Act of 1976. If the value of the acquisition does, in fact, trigger a filing and certain jurisdictional tests are met, the parties to the relevant transaction must fill in to the U.S. Federal Trade Commission and the U.S. Department of Justice. However, coverage under the Clayton Act for partial acquisitions is limited if the acquisition was made "solely for investment" purposes. ${ }^{166}$ The HSR Act includes an exemption from filing for a partial acquisition if the acquirer can show that the acquisition was made solely for the purpose of investment and that it will result in a level of ownership amounting to $10 \%$ or less of the voting securities of the issuer. ${ }^{167}$ In the case of institutional investors, this percentage is placed at $15 \%$ because it is presumed that their intention is not only centred on investment. Furthermore, to benefit from the exemption, the

\footnotetext{
${ }^{161}$ BSkyB v Competition Commission and the Secretary of State [2008] CAT 25.

${ }^{162}$ BSkyB v Competition Commission and the Secretary of State [2010] EWCA Civ 2.

${ }^{163}$ Competition Commission Report, Ryanair Holdings plc/Aer Lingus Group plc [2013].

${ }^{164}$ Id. 7.16-7.24.

16515 U.S.C. $\S 18$.

${ }^{166} \mathrm{Id}$.

${ }^{167}$ This presumption is narrowly construed. It does not apply if the issuer, whose stock is being acquired, is a competitor of the acquirer.
} 
stock must not be used "by voting or otherwise to bring about, or in attempting to bring about, the substantial lessening of competition" - a party seeking an exemption is required to prove that the purpose of the acquisition was not that of gaining control over the target company. ${ }^{168}$

One may also note another type of structural link targeted by US merger control, that of 'interlocking directorates'. This type of structural link involves situations in which an individual or entity serves on the Board or as an officer of two competing corporations and is a situation that has become more common as a result of the recent financialisation trend with private equity and hedge funds often investing in various companies active in the same industry. Under Section 8(a)(1) of the Clayton Act, "no person shall, at the same time, serve as a director or officer in any two corporations (other than banks, banking associations, and trust companies) that are ... by virtue of their business and location of operation, competitors, so that the elimination of competition by agreement between them would constitute a violation of any of the antitrust laws". ${ }^{169}$ The statute is interpreted as applying not only to natural persons or individuals but also to firms. However, there are a number of exemptions (for banks, banking associations, and trust companies or when the "competitive" sales of the interlocked firms fail to meet some thresholds (de minimis exceptions).

Therefore, it is accepted in various competition law regimes regarding merger control, excluding the EU, that the structural links that result from transactions that do not meet the legal definition of 'acquisition of control' or 'decisive influence', but in which the acquirer of non-controlling minority shareholdings gains the possibility of exercising material influence over the target, may lead, potentially, to significant anti-competitive effects. ${ }^{170}$

The literature distinguishes between full merger scenarios and partial concentration scenarios that involve the acquisition of minority shareholdings. "In a full merger scenario, the acquiring firm obtains $100 \%$ of the following types of rights over the target: i) 'control rights', and ii) 'cash flow rights'. Control rights allow the acquirer to influence the target's strategic decisions; hence they provide the acquirer with the ability to raise the target's prices. On the other hand, cash flow rights entitle the acquirer to have a financial interest - by means of its investment - and share in the profits of the target, hence they give the acquirer the incentive to raise the target's prices. Importantly, in the case of partial share ownership these two types of rights do not necessarily coincide and their relative proportions may be rather asymmetrical depending on the particularities of each commercial transaction or may even change from time to time. It follows that partial share ownership leads to two variants of the

\footnotetext{
${ }^{168}$ See United States v. Dairy Farmers of America, 426 F.3d 850 (6th Cir. 2005), which notes that "even without control or influence, an acquisition may still lessen competition" and constitute a violation of Section 8 of the Clayton Antitrust Act 1914.

169 15 U.S.C. $\S 19(4)$.

${ }^{170}$ It has been noted that "acquisitions of non-controlling minority shareholdings account for approximately 10$12 \%$ of all mergers notified in Germany and 5\% in the United Kingdom", the only jurisdictions (in addition to Austria) which currently have national merger control rules providing them with the competence to review structural links, such as minority shareholdings: see Commission Staff Working Document, "Impact Assessment", SWD(2014) 217 final, [38]. The Commission's "rough" estimates indicate that the number of cases of minority shareholdings that would meet the turnover thresholds of the Merger Regulation should be around $20-30 \%$ (or $7-10 \%$ of the merger cases currently examined by the Commission each year), which means that if the jurisdiction of the EUMR were extended to these cases, the Commission could intervene in another 12 cases per year: see (Id. 46).
} 
above-mentioned usual merger situation: i) it either gives only one type of rights (e.g. financial interests) but not the other one (e.g. control/influence), or ii) it partially gives both types of rights. This is crucial because the existence and degree of each type of right in a partial share acquisition has distinct implications for competition in that any combination of financial interests and control rights leads to different anticompetitive effects". ${ }^{171}$

Nevertheless, under the current EU competition law regime, minority shareholdings can be addressed in one of the following ways: ${ }^{172}$

- They may constitute 'decisive influence' under the EUMR, thereby constituting a concentration.

- They may be part of the substantive analysis of a concentration, e.g. minority shareholdings relevant to the assessment of whether there is a significant impediment to effective competition.

- There have been cases in which the merging parties have been willing to dispose of, or reduce, their stakes either before or during the Phase I administrative proceedings in order to obtain unconditional merger clearance, ${ }^{173}$ or to give formal commitments to divest, as a condition of clearance. ${ }^{174}$ However, had the same stake(s) been acquired post-acquisition, the Commission would have lacked the necessary powers to intervene. ${ }^{175}$

- In relation to the Commission's remedial powers, the Commission cannot order the unwinding of a non-controlling shareholding that was part of a failed takeover. Firstly, the remaining stake does not confer control over the target. Secondly, the proposed takeover has been prohibited and, thus, not fully implemented. The Ryanair/ Aer Lingus cases have exemplified this problem. Ryanair acquired shares in Aer Lingus on the stock exchange and, in parallel, launched a public bid. Although it had only been notified of the bid, the European Commission asserted jurisdiction over the combined stake-plus-offer. It treated the proposed acquisition as a single concentration and prohibited it. Thus, while the offer itself fell away, questions remained as to the stake. Although this had been part of a prohibited concentration, the Commission took the view that, by itself, it could not be the subject of a sell-down order under Article 8(4) of the EUMR, which focuses on the unwinding of completed/prohibited concentrations. The reason it could not be was because, by

\footnotetext{
${ }^{171}$ A. Tzanaki, The Legal Treatment of Minority Shareholdings under EU Competition Law: Present and Future, University of Piraeus Essay 861-886 (2015).

${ }^{172}$ A. Burnside, Minority Shareholdings: An Overview of EU and National Case Law, B. e-Comp. No. 56676 (2013).

${ }^{173}$ Id. See Case M.113 Courtaulds/SNIA [1991], in which there was a 12\% stake in a competitor; Case M.3547 Banco Santander/Abbey National [2004], which involved the modification of co-operation agreement between Santander and RBS, which included the termination of reciprocal board representation and a reduction of Santander's shareholding in RBS.

${ }^{174}$ Id. See Case M.1673 VEBA/VIAG [2000], which involved the disposal of various minority stakes to address concerns about joint dominance; Case M.5406 IPIC/MAN Ferrostaal [2009], which involved the divestment of MAN Ferrostaal's 30\% stake in Eurotecnica in order to address vertical concerns.

${ }^{175}$ M. Friend, Regulating Minority Shareholdings and Unintended Consequences, 33(6) Eur. Competit. Law Rev. 304-305 (2012).
} 
itself, the stake did not confer control. This position was upheld by the General Court. ${ }^{176}$

- Article 101 TFEU can apply to agreements in which a minority interest is acquired and Article 102 TFEU can apply to acquisitions by a dominant company. In the Philip Morris and the Gillette cases, these have Articles have been applied to minority shareholdings that give rise to "some (informal) influence" over the target, a threshold which may well be lower than the decisive influence (i.e. control) threshold required under the EUMR. However, Article 101 TFEU cannot be invoked unless it has been proven that there is an 'agreement' and/or 'concerted practice' between two or more undertakings linked to the minority share acquisition. Similarly, Article 102 TFEU only applies where it has been proven that there is a 'dominant' undertaking that has been 'abusive'.

In the Philip Morris judgment of $1984,{ }^{177}$ the European Court of Justice held that the mere acquisition of a minority stake could not in and of itself be said to amount to conduct restricting competition for the purposes of Article 101. Nevertheless, it held that such could serve as an instrument for influencing the commercial conduct of a competitor, thereby restricting or distorting competition, especially where the agreement provided for commercial co-operation or gave the acquiring shareholder the possibility of taking effective control of the target at a later stage. The Court emphasised the need to consider not just the immediate effects of the transaction but also the longer-term potential impact.

Article 101 TFEU applies to a number of agreements in which a minority interest may be acquired: ${ }^{178}$

- Joint ventures;

○ These joint ventures will not involve 'joint' control in the formal sense espoused under the EUMR. Typically, they will involve parent companies with holdings in a common vehicle.

- Production-only joint ventures;

$\circ$ These joint ventures will consist of joint control but will lack full functionality.

- A shareholding anchoring a commercial relationship;

○ For example, a supplier/customer relationship or strategic alliances.

- Complex ownership structures;

○ These will have been contrived in order to achieve a merger without having to transfer 'control'.

- Holding structures in which a company de facto neutralises a competitor; and

- Simple acquisition of a shareholding sold by a single vendor.

\footnotetext{
${ }^{176}$ See Case T-411/07 Aer Lingus Group Plc v European Commission [2011] ECR II-03691, [77]-[78], [84][85] and [87]; corresponding Commission Decision Ryanair/Aer Lingus (Case COMP/M.4439).

${ }^{177}$ Cases 142 and 156/84 British American Tobacco Co Ltd v Commission of the European Communities [1987] ECR 4487 (Philip Morris).

${ }^{178}$ See Burnside, supra, at 173, which notes that although it seems that Article 101 TFEU does not apply to situations in which a minority shareholding is acquired through purchasing the shares of a rival on the stock exchange from a number of unidentified counterparties, this issue remains unresolved.
} 
Regarding the possible application of Article 102 TFEU, the Court held that the acquisition of a minority shareholding in a competitor could only amount to an abuse where it resulted in effective control, or at least some influence, over the target's commercial policy. However, the judgment neither offered no guidance as to the level of influence that would be problematic nor as to the method by which to carry out the assessment. ${ }^{179}$

In the Warner-Lambert $v$ Gillette case, ${ }^{180}$ the Commission successfully challenged Gillette's acquisition of a $22 \%$ non-voting interest in the parent company of its major competitor, Wilkinson Sword, on the basis of it infringing Articles 101 and 102 TFEU. It is worth noting that there were various other commercial agreements in place, including an unsecured loan and the acquisition of certain trademarks outside of the EU and United States, but such fell short of control.

Given its potential for producing anti-competitive effects, ${ }^{181}$ the acquisition of minority shareholdings has attracted attention. ${ }^{182}$ The Commission has identified an 'enforcement gap' in respect of this type of acquisition, especially with regards to noncontrolling minority but influential (on business conduct) shareholdings in the context of merger control. The Commission has explored the possibility of improving the effectiveness of the EUMR by rendering it applicable to transactions that involve structural links. ${ }^{183}$

\section{B. Competition Law Framework for Common Ownership}

The EUMR's Jurisdictional Notice recognises that "sole control can be acquired on a de jure and/or de facto basis". ${ }^{184}$ With regard to the de facto basis, the Jurisdictional Notice espouses that the Commission should assess whether "the [minority] shareholder is highly likely to achieve a majority at the shareholders' meetings, given the level of its shareholding and the evidence resulting from the presence of shareholders in the shareholders' meetings in previous years". Indeed, "where, on the basis of its shareholding, the historic voting pattern at the shareholders' meeting and the position of other shareholders, a minority shareholder is likely to have a stable majority of the votes at the shareholders' meeting, then that large minority shareholder is taken to have sole control". ${ }^{185}$

A further element to take into account is the importance of shareholder fragmentation on effective control, in particular with regard to voting. The Commission has found in past cases that an institutional investor was able to exercise decisive influence over the target despite controlling 39\% shares as the rest was spread among more than 100000

\footnotetext{
${ }^{179}$ See Tzanaki, supra, at 172, 861-886, which refers to other similar cases are: Case IV/31.846 Enichem/ICI [1988] OJ L 50/18; Case IV/34.857 BT/MCI [1994] OJ L223/36; Case IV/34.410 Olivetti/Digital [1994] OJ L 309/24; Case IV/35.617 Phoenix/Global One [199] OJ L 239/57.

${ }^{180}$ Case IV/33.440 Warner-Lambert/Gillette [1993] OJ L 116.

${ }^{181}$ Commission Staff, supra, at 170.

${ }^{182}$ European Commission, Modernisation of the Rules Implementing Articles 85 and 86 of the EC Treaty, White Paper Commission Programme No. 99/027 (1999) .

${ }^{183}$ See Commission Staff, supra at 170, Part 3; Spark Legal Network and Queen Mary University of London, Support Study for Impact Assessment Concerning the Review Of Merger Regulation Regarding Minority Shareholdings, European Commission Final Report (2016) .

${ }^{184}$ Jurisdictional Notice, supra, at 144, 55.

185 Id. 59.
} 
shareholders. ${ }^{186}$ In a similar vein, the Commission has found that a capital participation of $25.96 \%$ was sufficient to lead to a change of ownership or control, which was largely due to the level of participation in general meetings. ${ }^{187}$ The dispersion of voting rights between a large number of minority shareholders has also led the Commission, in certain cases, to accept that holding a significant proportion of the effective voting rights could signal control. In the case of RTL, its holding of $34 \%$ of the effective voting rights (although it held $48.39 \%$ of the shares, the voting rights were limited by regulation) signalled control and this conclusion was bolstered by the shareholders' past record in relation to presence in meetings and the highly unlikely possibility of them coalescing around, and giving majority support via votes, to a particular proposal. ${ }^{188}$ Equally though, it should be noted that a merger transaction may increase the level of participation of certain shareholders in the new entity and, eventually, their ability to establish control.

Beyond the issue of a simple minority shareholding resulting in said shareholder(s) effectively controlling a company's strategy, a related issue is whether it is also possible to find anti-competitive effects on the basis of the common institutional investors being both present and significant players in a specific market, ie.. whether it is possible to find anticompetitive effects on the basis of partial competitor ownership.

In paragraph 20(c) of the EU Horizontal Merger Guidelines, it is accepted that crossownership may give rise to anti-competitive effects: "the Commission is ... unlikely to identify horizontal competition concerns in a merger with a post-merger [HerfindahlHirschman Index ('HHI')] HHI between 1000 and 2000 and a delta below 250, or a merger with a post-merger HHI above 2000 and a delta below 150, except where special circumstances such as, for instance, one or more of the following factors are present: ... (c) there are significant cross-shareholdings among the market participants".

Cross-ownership may also provide a for channel for information channel to be exchanged between competitors. ${ }^{189}$ Thus, it may provide "help in aligning the incentives of the coordinating firms". 190

The Merger Guidelines do not, however, mention situations of common ownership. The Commission felt that it lacked the necessary tools for dealing with anti-competitive acquisitions of minority shareholdings in general, and with common ownership in particular. In its 2014 White Paper on effective merger control, the Commission advocated for a targeted transparency system. It contended that this system would be well-suited to capturing such transactions and, thereby preventing consumer harm. ${ }^{191}$ The parties would have to self-assess whether a transaction creates a "competitively significant link" and, if so, submit an

\footnotetext{
${ }^{186}$ See Case IV/M.025 Arjomari/Wiggins Teape Appleton [1990] OJ C321, 16; Case IV/M.764 Saint Gobain/Poliet [2000] OJ C225, 8. Note that according to the takeover directive [Directive 2004/25/EC of the European Parliament and of the Council of 21 april 2004 on takeover bids, (2004) OJ L 142/12] and the City Code for Takeovers and Mergers the threshold for a mandatory bid rule is $30 \%$ of the voting stock. This was set because at $30 \%$ there is a presumption of change in control in listed companies. Note that this was done in an environment mostly dominated by block-holders.

${ }^{187}$ Case IV/M.343 Société Générale de Belgique/Générale de Banque [1993] OJ C225, 2.

${ }^{188}$ Case M.3330 RTL/M6 [2004] OJ C95, 35.

${ }^{189}$ Recital 47 of the EUMR, (141).

${ }^{190}$ Id. Recital 48.

${ }^{191}$ European Commission, Towards More Effective EU Merger Control, White Paper COM(2014) 449 final 43 (2014).
} 
'information notice'. In the event that an information notice were to be submitted, the Commission would then decide whether to investigate the transaction and the Member States would decide whether to make a referral request. ${ }^{192}$ The theme of minority shareholdings was, however, omitted in the most recent merger control consultation launched by Commissioner Vestager, thereby bringing the process of reforming the EUMR in regard to this issue to a standstill. ${ }^{193}$

The Commission realised that the EUMR's focus on the acquisition of control largely ignores the risks for competition associated with the acquisition of a passive minority interest. ${ }^{194}$ It fails to consider the potential anti-competitive effects that may result from the indirect and/or informal influence that may be exercised by passive investors, despite them not having 'control'. As previously mentioned, recent empirical analyses of the U.S. airline industry ${ }^{195}$ and banking industry ${ }^{196}$ measured the potential (large) effect of common ownership on price levels rising above the competitive ones. These findings have resulted in i) policy concerns, which have been expressed by economists ${ }^{197}$ and lawyers, ${ }^{198}$ ii) proposals for legislative intervention, ${ }^{199}$ and iii) criticism of the findings themselves. ${ }^{200}$ The acquisition of minority shareholdings has also been a focus of the European Commission. ${ }^{201}$ It has identified an 'enforcement gap' in respect of these types of acquisitions, especially with regards to non-controlling minority shareholdings. It has also recognised a number of anticompetitive effects that may potentially emerge from minority shareholdings, including unilateral effects, coordinated effects and vertical foreclosure. ${ }^{202}$ The finding that there is some causal link between common ownership and price levels have led some authors to argue for the systematic scrutiny by competition law and its enforcement authorities of common ownership situations as well as consideration of the specific types of remedies that could apply.

Indeed, economic and legal literature has recently triggered a number of proposals concerning legislative intervention, all of which have varying levels of stringency. Elhauge takes a radical stance. ${ }^{203} \mathrm{He}$ claims that stock acquisitions that create anti-competitive horizontal shareholdings should be considered illegal under current antitrust law. He calls for the break-up of the existing shareholdings and cites a range of negative outcomes, such as corporate executives being rewarded for industry performance rather than solely for individual corporate performance, corporations not using recent high profits to expand output and employment, and the rise in economic inequality over recent decades.

\footnotetext{
192 Id. 48.

193 European Commission, Consultation on Evaluation of Procedural and Jurisdictional Aspects of EU Merger Control (2017), <http://ec.europa.eu/competition/consultations/2016_merger_control/index_en.html>.

194 OECD, Antitrust Issues Involving Minority Shareholdings and Interlocking Directorates, Report DAF/COMP(2008)30 21 (2008).

${ }^{195}$ Azar et al., supra, at 37.

${ }^{196}$ Azar et al., supra, at 38.

${ }^{197}$ Council of Economic Advisors, supra, at 39.

${ }^{198}$ E. Elhauge, supra, at 40, 1267.

${ }^{199}$ Posner et al., supra, at 34.

${ }^{200}$ See Rock and Rubinfeld, supra, at 42; Rock and Rubinfeld, supra at 43.

${ }^{201}$ Commission, supra, at 182.

${ }^{202}$ Commission Staff, supra, at 170.

${ }^{203}$ Elhauge, supra, at 40, 1267.
} 
Posner, Morton and Weyl question whether direct application Section 7 of the Clayton Act would be beneficial or whether it would, simultaneously, cause market disruption whilst failing to eliminate most of the harms stemming from common ownership. ${ }^{204}$ They present evidence from simulations of the market outcomes deriving from the sufficient anti-monopolistic conditions for the model used in AST. ${ }^{205}$ Their simulationdriven evidence suggests that limiting investors to holding up to $1 \%$ of a company's equity per oligopoly or shares of a single company in any oligopoly is a sufficient condition. Therefore, they propose a public enforcement policy that will grant a safe harbour to investors who voluntarily reduce their portfolio in order to satisfy either of the two conditions. Note, however, that picking a single company in a sector raises important marketdefinition questions. As pointed out in recent media discussions: "can you invest in both Facebook and Google, or are they in the same industry?"206 Should we rely on relevant markets, rather than industries, instead?

Rock and Rubinfeld propose a much wider safe harbour. ${ }^{207}$ They suggest protection from antitrust liability for investors whose ownership share is below $15 \%$, are not represented on the board and only engage in "normal" corporate governance activities. Notably, this approach does not remove the financial incentive aspect of common ownership; it concentrates purely on corporate control. Also the limitations proposed in relating to voting rights fail to address the concern that shareholders may simply fail to exercise their corporate governance rights in the way that prioritises a profit-maximising strategy for a single firm over the industry performance. Elhauge presents the example of DuPont's diversified shareholders who rejected an activist effort to (arguably) compete more vigorously against Monsanto. ${ }^{208}$ Furthermore, institutional investors, such as index funds, would likely argue that they are under a duty to their individual investors to protect their interests and, thus, must exercise good governance when deciding the firms into which they wish to invest. Thus, voting rights are the instrument by which they can implement the (expressed) interests of their investors.

There are also significant concerns about market distortions, which may be caused by either form of legislative intervention. Posner, Morton and Weyl raise an important concern about potential interventions leading to a single investor becoming a significant common owner without taking a direct action, but simply led by actions of other investors on the market. ${ }^{209}$ The authors warn that private litigation and/or unguided public litigation could cause problems because of the interactive nature of institutional holdings on competition. Given that the proposed MHHI indexes evaluate market concentrations through the relative weights of investors' portfolios, the investment of one institutional investor in competing firms affects the amount by which another institutional investor lessens competition with its investments in the same industry. Consequently, institutions could become liable simply

\footnotetext{
${ }^{204}$ Posner et al., supra, at 34.

205 Azar et al., supra, at 37.

206 M. Levine, Index Funds May Work a Little Too Well, bloomberg.com (2015), <https://www.bloomberg.com/opinion/articles/2015-07-22/index-funds-may-work-a-little-too-well>.

${ }^{207}$ Rock and Rubinfeld, supra, at 43.

${ }^{208}$ Elhauge, supra, at 40, 1267.

${ }^{209}$ Posner et al., supra, at 34).
} 
because other institutions have changed their holdings and, thereby, made the relevant industry less competitive. The introduction of stringent legislation that would oblige institutional investors to determine the ownership shares of other institutions and their expected volatility would put them into a difficult and unclear position as to the ways and financial instruments into which they could legally invest.

Having reviewed the literature, we find the intuitions captured in Azar's mechanisms to be a reasonable concern about the effect of common ownership on market competition. ${ }^{210}$ Given the recent emergence of measurement techniques and empirical estimation methods in this area, we are not overly concerned with the criticisms expressed by some authors in regard to this issue, although we do acknowledge the need for improvement. However, we are deeply concerned with the issue, and consequent debate, concerning the incentives of firms in the market being distorted away from competition by the presence of institutional investors - and we have not found any sufficiently convincing counterarguments to allay this concern. Ultimately, policy-makers are sceptical as to whether common ownership undermines competition by altering the incentives of the manager of the relevant firm manager's incentives or by something else. The focus on policy-makers remains set on the possible eventual unilateral effects and/or collusive outcomes. Therefore, the main test whether these collusive outcomes and/or anti-competitive effects are facilitated by the presence of financial investors.

C. Common Ownership in the Food Value Chain and Innovation Effects: The AgroChem Mergers

It is worth noting some of the recent analysis conducted by the Commission as the possible effects of common ownership on incentives to innovate. In assessing the recent agrochem mergers, the Commission provided its first, in-depth examination of the possible anticompetitive effects of common shareholding on innovation incentives. ${ }^{211}$

The Commission thoroughly examined the possible anti-competitive effects of common shareholding on innovation incentives in the Dow/DuPont merger case, setting out its views in both the decision and its Annex. ${ }^{212}$ The Commission's starting point was that shares in the industry tend to underestimate the expected non-coordinated effects of the merger, due to the significant level of cross-shareholding between the main players. The Commission provided factual evidence of the significant level of common shareholding in the agro-chemical industry and the involvement of large minority shareholders, which, despite being labelled by some as "passive investors", are, in fact, "active owners". The Commission noted that the existence of a significant level of common shareholding tends to lower rivalry. This finding was based on the economic literature on cross-shareholdings, "which extends to common shareholding", and "tends to show that common shareholding of competitors reduces incentives to compete as the benefits of competing aggressively to one firm come at

\footnotetext{
${ }^{210}$ Azar, supra, at 53.

${ }^{211}$ Dow/DuPont Decision, supra, at 131.

${ }^{212} \underline{\text { Id. }}$
} 
the expense of firms that belong to the same investors' portfolio". ${ }^{213}$ This literature has been discussed in great detail in the previous Parts of this Chapter.

The Commission proceeded by considering recent empirical studies, ${ }^{214}$ which indicated that the presence of significant common shareholding in an industry is "likely to have material consequences on the behaviour of the firms in such industries". ${ }^{215}$ Indeed, the core argument put forward by the literature focusing on the anticompetitive effects of common ownership is that the existence of significant common shareholding may result in higher prices, due to the fact that common shareholders tend to shape the monetary incentives of the relevant firms' executives in order to align them with industry performance, which they (the common shareholders) shape so that such provides the best returns for them across the industry and not only their firm's specific performance. ${ }^{216}$ The Commission has transposed this literature focusing on the price effects of common ownership to the situation of innovation competition, which allegedly may also be reduced by such cross- and common ownership. ${ }^{217}$ The Commission stated that "by increasing its efforts in R\&D, a firm incurs a cost that decreases its current profits in expectation of future benefits brought by the resulting products of its innovation. Such future benefits would necessarily materialise through price competition of future products, which, given the specificities of the agro-chemical industry, in particular the fact that the total size of the crop protection industry is typically not related to innovation, is likely to be mainly at the expense of its competitors. In other words, the decision taken by one firm, today, to increase innovation competition has a downward impact on its current profits and is also likely to have a downward impact on the (expected future) profits of its competitors. This, in turn, will negatively affect the value of the portfolio of shareholders who hold positions in this firm and in its competitors. Therefore, as for current price competition, the presence of significant common shareholding is likely to negatively affect the benefits of innovation competition for firms subject to this common shareholding". 218

Common ownership has also been considered as having the potential to produce unilateral effects, as is explained in Annex 5 of the Commission's decision in Dow/DuPont: "for the sake of the argument, assume that a firm (the 'acquiring firm') acquires a minority share in a competitor (the 'partially acquired firm'). When contemplating a price increase, the acquiring firm anticipates that part of its customers will react to this price increase by diverting their purchase to its competitors, which will see their sales increase, including the one in which it has a minority share. The extra profits generated by the diverted sales to the benefit of the partially acquired firm will, in turn, be partially redistributed to the acquiring firm. As a consequence, when holding a minority share in a competitor, the acquiring firm has higher incentives to increase its prices than in the absence of such a minority share". ${ }^{219}$ Thus, "the impact on the acquired firm's incentives depends on how the transaction affects

\footnotetext{
213 Id. 2348.

${ }^{214}$ In particular, Azar et al., supra, at 37.

${ }^{215}$ Dow/DuPont, supra, at 131, 2349.

${ }^{216}$ See, for a summary of this argument, Anton et al., supra at 71.

${ }^{217}$ Dow/DuPont supra at 131, 2350.

${ }^{218}$ Id. 2351 and Annex 5, 59.

${ }^{219}$ Id. Annex 5, 43.
} 
the governance of the acquired firm, that is on the acquiring firm's degree of control, which can range from no control at all (silent financial interest), to partial control, to total control". 220

Hence, for the Commission, measures of concentration, such as market shares or the HHI, are likely to underestimate the level of concentration and, thus, the market power of the merging parties. Common shareholding is a reality in the agro-chemical industry, in terms of both the number of common shareholders and the level of shares possessed by these common shareholders. Hence, the Commission took these contextual elements into account when seeking to determine effective competition had been significantly impeded. It noted that such a finding would indicate that innovation competition in crop protection is likely to be less intense than in an industry with no common shareholding. ${ }^{221}$

The Commission re-affirmed its stance in the Bayer/Monsanto merger. It noted that "(i) concentration measures, such as market shares or the HHI, are likely to underestimate the level of concentration of the market structure and, thus, the market power of the parties, (ii) common shareholding is a reality in the biotech and agro-chemical industry, both in terms of the number of common shareholders as well as with respect to the level of shares possessed by these common shareholders, and, thus, (iii) common shareholding in these industries are to be taken as an element of context in the appreciation of any significant impediment to effective competition". ${ }^{222}$ However, the issue was not explored further in the Commission's decision when assessing the anti-competitive effects of the merger transaction; the Commission simply considered it when it examined whether BASF was a 'suitable purchaser', in the sense of paragraph 48 of the Remedies Notice, given the overlap in shareholding between BASF and the merged entity. ${ }^{223}$ The Commission noted that "since common shareholdings are a reality in the biotech and agro-chemical industry, this feature should be taken into account as an element of context at the time of the purchaser assessment, but should not, as such, disqualify BASF prima facie as a suitable purchaser for the purposes of this Decision". ${ }^{224}$ It then highlighted that the debate as the anti-competitive effects of common ownership is "relatively recent and not yet entirely settled". ${ }^{225}$ As the Commission's remedial goal was to "replicate the role of Bayer in the market absent the transaction", the common shareholding observed with regard to BASF would not have made any difference to either the existing level of common ownership or the incentives to compete in the market. ${ }^{226}$ In its decision, the Commission did not analyse the possible effects of common ownership on the incentives of the remaining big players in the industry to compete. The Commission also refused to take the broader competitive picture into consideration, noting that the market power of BASF and the divested businesses should be examined in the "relevant product and geographic markets and not abstractly at industry level". 227

\footnotetext{
${ }^{220}$ Id. 45 .

${ }_{221}$ Dow/DuPont, supra, at 131, 2352.

${ }^{222}$ Commission Decision, Case M-8084 Bayer/Monsanto (2018), 228.

${ }^{223}$ Id. 3302-3307.

224 Id. 3303.

225 Id. 3304.

226 Id. 3305.

227 Id. 3307.
} 


\section{Conclusion}

This study examined the implications of the financialisation process for competition law enforcement. We explored the possibility that common ownership may constitute a competition concern, raising issues of unilateral effects, horizontal collusion, vertical exclusion and vertical exploitation. This discussion is particularly important in the context of the FVC, with the rise of common ownership as one of the manifestations of the broader trend of financialisation of the food industry. Many institutional investors are passive investors in the diverse companies that are active at various segments of the FVC. Although this paper focused solely on the seed/agro-chem sector, it is possible to identify considerable common ownership in other parts of the FVC as well, particularly in the segments with the highest levels of economic concentration. In view of the possible negative welfare effects of common ownership on competition and its prevalence in the food sector, it is contended that competition authorities need to develop adequate legal tools to deal with this issue and rely on economics but also other sources of wisdom (e.g. advanced social network analysis) that may enable a better mapping of the complexity of competitive interactions in this sector and be more adequate in the context of a complex economy. 
Annex 1: Share ownership of the most infuential investors into the global food value chain (sorted by page rank) - Source: Authors' Calculations on the basis of Bloomberg data (access date - June 12, 2017)

\begin{tabular}{|c|c|c|c|c|c|c|c|c|c|c|c|c|c|c|c|}
\hline \multirow{3}{*}{ Investor } & \multicolumn{15}{|c|}{ Percentage shares owned } \\
\hline & \multicolumn{2}{|c|}{$\begin{array}{l}\text { Animal } \\
\text { Safety }\end{array}$} & \multicolumn{2}{|c|}{$\begin{array}{c}\text { Biotech / } \\
\text { Animal } \\
\text { genomics }\end{array}$} & \multicolumn{3}{|c|}{$\begin{array}{l}\text { Seeds \& Crop } \\
\text { Protection }\end{array}$} & \multicolumn{2}{|c|}{ Fertilisers } & \multicolumn{2}{|c|}{$\begin{array}{c}\text { Farm } \\
\text { Machinery }\end{array}$} & \multicolumn{4}{|c|}{ Food, diversified companies } \\
\hline & 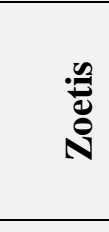 & 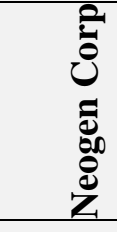 & $\stackrel{\text { 涪 }}{\text { 豆 }}$ & $\stackrel{\mathscr{E}}{0}$ & 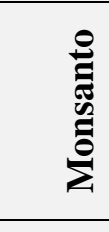 & $\begin{array}{l}\overrightarrow{0} \\
E \\
E\end{array}$ & है & 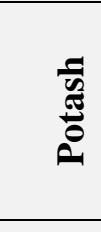 & 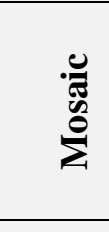 & 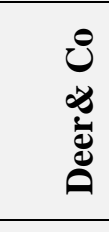 & 己 & 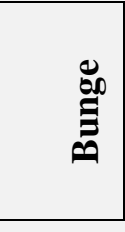 & 窟 & 己ु & $\begin{array}{l}0 \\
\overline{0} \\
8 \\
0 \\
0 \\
0 \\
0 \\
0 \\
0\end{array}$ \\
\hline BlackRock Inc & 7.35 & 11.72 & 7.33 & 4.56 & 5.97 & 6.31 & 6.58 & 4.75 & 7.12 & 5.23 & 8.21 & 5.69 & 6.91 & 6.34 & 6.61 \\
\hline Vanguard Group & 6.67 & 8.55 & 6.61 & 2.4 & 6.82 & 6.99 & 6.65 & 2.31 & 7.12 & 6.39 & 7.1 & 10.01 & 7.64 & 10.88 & 8.36 \\
\hline State Street Corp & 4.33 & 2.38 & 4.15 & 0.59 & 4.59 & 4.91 & 3.97 & 0.14 & 5.57 & 3.84 & 4.16 & 3.02 & 5.79 & 4.29 & 4.86 \\
\hline FMR LLC & 0.21 & 0.82 & 0.54 & 0 & 2.88 & 3.73 & 1.27 & 3.2 & 1.46 & 1.33 & 1.63 & 2.86 & 0.16 & 0.19 & 0.27 \\
\hline $\begin{array}{c}\text { Capital Group } \\
\text { Companies }\end{array}$ & 0 & 0 & 10.57 & 0 & 2.98 & 10.25 & 3.74 & 5.34 & 5.16 & 2.91 & 0 & 0 & 0 & 2.08 & 0 \\
\hline $\begin{array}{c}\text { Dimensional Fund } \\
\text { Advisors LP } \\
\end{array}$ & 0.27 & 1.7 & 0.18 & 1.08 & 0.23 & 0.18 & 0.34 & 0.27 & 1.05 & 0.29 & 3.51 & 1.48 & 0.95 & 0.32 & 1.39 \\
\hline
\end{tabular}




\begin{tabular}{|c|c|c|c|c|c|c|c|c|c|c|c|c|c|c|c|}
\hline T Rowe Price & 8.19 & 0.03 & 4.33 & 1.42 & 0.33 & 2.29 & 0.17 & 0 & 0.81 & 0.19 & 1.44 & 6.76 & 2.11 & 2.29 & 10.57 \\
\hline Morgan Stanley & 2.99 & 0.38 & 3.02 & 0.34 & 0.54 & 0.51 & 0.53 & 0.45 & 1.46 & 0.43 & 1.44 & 0.58 & 0.42 & 1.56 & 0.39 \\
\hline BNY Mellon & 1.11 & 1.39 & 0.85 & 0 & 0.9 & 1.04 & 1.35 & 0.39 & 2.99 & 0.8 & 1.13 & 0.36 & 1.35 & 1.92 & 1.8 \\
\hline TIAA - CREF & 1.99 & 0.44 & 0.93 & 0.12 & 0.73 & 0.47 & 1.07 & 0.15 & 0.37 & 0.55 & 2.03 & 1.43 & 0.47 & 2.42 & 1.21 \\
\hline Goldman Sachs & 1.03 & 0.3 & 0.96 & 0.15 & 0.7 & 0.83 & 0.47 & 0.22 & 0.49 & 0.32 & 0.91 & 1.59 & 0.66 & 1.4 & 1.66 \\
\hline $\begin{array}{c}\text { Share owned by top-11 } \\
\text { investors }\end{array}$ & 34.14 & 27.71 & 39.47 & 10.66 & 26.67 & 37.51 & 26.14 & 17.22 & 33.6 & 22.28 & 31.56 & 33.78 & 26.46 & 33.69 & 37.12 \\
\hline
\end{tabular}

